DESCRIPTIONS OF SPECIES OF PLEISTOCENE VERTEBRATA, TYPES OR SPECIMENS OF MOST OF WHICH ARE PRESERVED IN THE UNITED STATES NATIONAL MUSEUM.

\author{
By Oliver P. Hay, \\ Associate of the Carnegie Institution of Washington.
}

INTRODUCTION.

In the paper which follows there are described fossil remains of Pleistocene Mammalia, which have been found at three principal places: Denver, Colorado; Wenatchee, Chelan County, Washington; and Anita, Coconino County, Arizona. In addition to the species from these places there are described remains of camels and of rodents and lagomorphs from various localities west of the Mississippi River; also bones of a sloth from near Williston, Levy County, Florida.

1. COLLECTION OF FOSSIL VERTEBRATE REMAINS FOUND AT DENVER, COLORADO.

In the United States National Museum there is a small collection of fossil mammals which was presented in 1915 by Prof. George L. Cannon, of the Eastern High School of Denver. Nearly all of these remains had been found by Mr. E. Blackburn, about 1902, and given to Professor Cannon. They had been discovered mostly about onehalf mile south of Fairmount Cemetery, on the western side of Platte River, in the fine deposit which was laid down by Platte River and regarded sometimes as loess. The depths at which the bones were found are not known. The Quaternary geology of the quadrangle has been described by Dr. S. F. Emmons, aided by Professor Cannon. ${ }^{1}$ According to the geological map of that quadrangle, ${ }^{2}$ the Quaternary deposits along the Platte consist of ancient river drift (Terrace) and of a later alluvium. The former is mapped along the eastern shore of the river from Denver northward. On the western-shore there is indicated only the later alluvium. Nevertheless, in this later deposit there have been found remains of horses and camels. The present writer believes that these deposits are about as old as the first interglacial stage. It can not be said that deposits laid down at an early

${ }^{1}$ Mon. U. S. Geol. Surv., vol. 27, 1896, pp. 255-278.

Idem, pl. 2.

Proceedings U. S. National Museum, Vol. 59-No. 239 I. 
period and containing camel bones had been reworked during a later Pleistocene time; for there is present the lower end of the fore-arm, all the bones of the wrist (except the pisiform), and the upper end of the cannon bone, evidently of one individual.

The remains obtained from Professor Cannon are identified as follows: Equus, species indeterminable; Camelops huerfanensis; Bison, species indeterminable.

Besides these there is present an astragalus of a prong-horn antelope, but there is no certainty that it is not that of a comparatively recent individual.

EQUUS, species indeterminable.

An indeterminable species of horse is represented by a right third metacarpal (Cat. No. 8217), a left metatarsal (Cat. No. 8216), and an anterior first phalanx. These have the appearance of having lain in the same kind of deposit and may have belonged to the same individual. The metacarpal has a total length of $244 \mathrm{~mm}$. and a side-to-side diameter of $37 \mathrm{~mm}$. at the middle of the length. The total length of the metatarsal is $268 \mathrm{~mm}$.; its side-to-side diameter at the middle of the length, $37 \mathrm{~mm}$. The length of the phalange is $78 \mathrm{~mm}$.

\section{CAMELOPS HUERFANENSIS.}

Plate 116, figs. 1-7.

What is believed to be Camelops huerfanensis is represented by a number of fine teeth and by various bones. It is not known to what extent the various bones and teeth were associated, but the teeth were not probably found with the bones. Measurements are presented both of the teeth, and of some of the bones. Such measurements may be of use in the identification of other remains. The teeth are to be compared with those of the type of Camelops huerfanensis (Cragin). Those from Denver consist of a right fourth premolar (pl. 116, fig. 1); a right first molar (pl. 116, figs. 2, 3); a right second molar (pl. 116, figs. 4, 5) ; a right third molar (pl.116, fig. 6); all of the upper jaw. There is, besides, a lower left second molar which appears not to have belonged to this individual, but to another of about the same age. All of these teeth are those of animals mature, but yet young. The hindermost molars are but little worn; and all may be said to be in prime condition. In the table of measurements here presented the height is given merely to indicate the stage of wear. The specimen described by Cragin was a somewhat older animal. In the columns showing the fore-and-aft lengths the first number, where there are two, indicates the length at the summit; the numbers in parentheses, the length taken near the base. The first number varies with the amount of wear. The width is taken near the base of the front lobe. The numbers in parentheses in the 
first column are those assigned in the catalogue of the department of vertebrate paleontology in the United States National Museum.

Table of measurements of teeth of Camelops huerfanensis.

\begin{tabular}{|c|c|c|c|c|c|c|}
\hline \multirow{2}{*}{ Tooth. } & \multicolumn{2}{|c|}{ Height. } & \multicolumn{2}{|c|}{ Length. } & \multicolumn{2}{|c|}{ Width. } \\
\hline & Type. & Denver. & Type. & Denver. & Type. & Denver. \\
\hline $\begin{array}{l}\text { Pm } 4(8248 a) \\
\text { M } 1(8248 b) \ldots \\
\text { M } 2(8248 c) \ldots \\
\text { M } 3(8248 d) \ldots\end{array}$ & $\begin{array}{l}38 \\
35 \\
55 \\
63\end{array}$ & $\begin{array}{l}43 \\
50 \\
70 \\
62\end{array}$ & $\begin{array}{l}27(22) \\
40(32) \\
50(35) \\
56(54)\end{array}$ & $\begin{array}{l}24 \pm(-) \\
41 \quad(29) \\
49 \quad(35) \\
41 \quad(46)\end{array}$ & $\begin{array}{l}25 \\
30 \\
31 \\
31\end{array}$ & $\begin{array}{l}26 \\
30 \\
30 \\
29 \pm\end{array}$ \\
\hline
\end{tabular}

On comparison of the structure of the teeth of Cragin's type specimen and that from Denver, few differences are observed, and these are probably not important. The median style of the Denver teeth is more undercut than in the type specimen, and the spaces between the styles are somewhat more elevated. In the figure showing the grinding surfaces the latter appear much broader in the type than in the Denver specimen, but this is because the teeth of the type are worn down farther toward the base.

There are some lower teeth to be described.

Table of measurements of lower teeth of C. huerfanensis.

\begin{tabular}{|c|c|c|c|c|c|c|}
\hline s. & \multicolumn{2}{|c|}{ Height. } & \multicolumn{2}{|c|}{ Length. } & \multicolumn{2}{|c|}{ Width. } \\
\hline & Type. & Denver. & Type. & Denver. & Type. & Denver. \\
\hline $\begin{array}{l}\text { M } 2(8247) \ldots . \\
\text { M } 3(8248 f) \ldots\end{array}$ & $\begin{array}{l}55 \pm \\
65 \pm\end{array}$ & $\begin{array}{l}60 \pm \\
76 \pm\end{array}$ & $\begin{array}{l}45(-) \\
62(-)\end{array}$ & $\begin{array}{l}50(32) \\
51(61)\end{array}$ & $\begin{array}{l}24 \\
21\end{array}$ & $\begin{array}{l}19 \\
22\end{array}$ \\
\hline
\end{tabular}

Inasmuch as the lower teeth of the type of $C$. huerfanensis are to a considerable extent hidden in the bone, some of their dimensions can not be secured. The right lower second molar from Denver is a thinner tooth than the corresponding one of the type. It is possible, of course, that this Denver tooth did not belong to the same species as the other teeth. Leidy ${ }^{3}$ referred a lower second molar to his Megalomeryx niobrarensis. In its less wedgelike form it is different from the corresponding molar from Denver, and it is larger; otherwise the teeth are not greatly different. The lower left hindermost molar is represented by figure 7 of plate 116 . The Denver teeth appear not to be much different from camel teeth found at Minidoka, Idaho, and described by the writer in $1913 .^{4}$ In the United States National Museum there is a lower left hindermost molar (Cat. No. 8252) of a camel which was sent from Wakonda, Turner County, South Dakota.

3 Extinct Mamm. Fauna Dak. Neb., 1869, pl. 14, fig. 12.

Proc. U. S. Nat. Mus., vol. 46, pp. 273-275. 
It was found in a gravel pit at a depth of 9 feet. Figures are presented of this tooth (pl. 116, figs. 8, 9). It is characterized by its thickness, the strong development of the styles, the angulation of the inner faces of the lobes, and the unequal slopes of the front and rear portions of their faces. The crown is worn down to about one-half of its original height; the length is $64 \mathrm{~mm}$.; the width of the front lobe, at the base, $28 \mathrm{~mm}$. It can hardly belong to $C$. huerfanensis.

A scapula from Denver is represented by about $150 \mathrm{~mm}$. of the base of that of the left side (Cat. No. 8228). The greater diameter of the glenoid cavity is $77 \mathrm{~mm}$.; the shorter, $64 \mathrm{~mm}$. The width of the bone from its rear border to the front of the coracoid process is $118 \mathrm{~mm}$. The bone differs from that of the dromedary in having along the hinder border of the subscapular surface a prominent ridge. This fades out as it approaches the glenoid fossa.

The humerus is represented by the distal end of three bones-two of the left limb, one of the right. One of those of the left side (Cat. No. 8236) is large, measuring $91 \mathrm{~mm}$. across the articular surface for the forearm. In the specimen of dromedary at hand (Cat. No. 143158, U. S. Nat. Mus.) this width is only $77 \mathrm{~mm}$. The other fragment (Cat. No. 8229) of a left humerus and the one of the right (Cat. No. 8231) belonged probably to the same individual, and measure across the articular surface $81 \mathrm{~mm}$. The fossa for the olecranon is, however, narrower $(30 \mathrm{~mm}$.) than in the dromedary $(35 \mathrm{~mm}$.).

Of the ulno-radius there are present the proximal end of one of the left side (Cat. No. 8233) and two distal ends of the left side. It is probable that the proximal end belonged to the smaller individual, that which possessed the distal end of the right humerus above described. Judging from the color of the bones the writer concludes that one (Cat. No. 8227) of the distal ends was a part of the same bone as the fragment (Cat. No. 8233) just described. The surface which articulated with the wrist bones is $81 \mathrm{~mm}$. wide; in the dromedary it is $78 \mathrm{~mm}$. wide. The other distal end of a forearm bone (Cat. No. 8232) has the same size as the one just mentioned. It is of a lighter color. The browner bone has been much gnawed by some broad-toothed rodent, probably a porcupine. The bone last mentioned brings with it all of the carpals except the pisiform. Those of the upper row have a height of about $37 \mathrm{~mm}$.; those of the lower row, of about $22 \mathrm{~mm}$. These carpals are followed by about $100 \mathrm{~mm}$. of the anterior cannon bone. This has a width, across the proximal articular surface, of $78 \mathrm{~mm}$. There is, besides, a second proximal end of a cannon bone (Cat. No. 8234) of the same size. The corresponding surface of the dromedary measures only $68 \mathrm{~mm}$. from side to side. It is evident, too, that the shaft of this bone in the fossil had a considerably greater diameter than that of the dromedary, although the bones higher up in the leg were not greatly larger. The larger frag- 
ment of the humerus mentioned above (Cat. No. 8230) is too large to fit into the upper end of the ulno-radius present.

There are present the distal ends of two cannon bones. One (Cat. No. 8238) is taken to belong to a foreleg; the other (Cat. No. 8237) to a hinder leg. The former is the larger. The articular surfaces are damaged, but the distance across the end was close to 92 $\mathrm{mm}$. Across one of the articular surfaces the width is $43 \mathrm{~mm}$. At a distance of $75 \mathrm{~mm}$. above the distal end of the bone the width of the shaft is $66 \mathrm{~mm}$., the thickness $30 \mathrm{~mm}$. The split between the two divisions does not reach quite to this height. One proximal phalange is present (Cat. No. 8239). The length is $102 \mathrm{~mm}$; the width of the proximal end is $42 \mathrm{~mm}$; of the distal end, $33 \mathrm{~mm}$. At the middle of the length the side-to-side diameter is $22 \mathrm{~mm}$; the fore-and-aft, $22 \mathrm{~mm}$. This bone is slightly longer than the hinder first phalange in the dromedary. The upper and middle diameters of both species are about the same. The lower articular surfaces of the fossil bone are abraded somewhat, but it is hardly probable that they were expanded laterally as much as in the dromedary. A right navicular (Cat. No. 8246), somewhat large for the astragalus 8244 , has a fore-and-aft diameter of $50 \mathrm{~mm}$; a side-to-side diameter of $30 \mathrm{~mm}$.

Of the left innominate bone there is a piece (Cat. No. 8240) a little more than $200 \mathrm{~mm}$. long. The diameters of the acetabulum are $70 \mathrm{~mm}$.

The cannon bone mentioned above as a supposed hinder one has each of the articular surfaces $38 \mathrm{~mm}$. wide. The distance across both is $85 \mathrm{~mm}$. At a height of $75 \mathrm{~mm}$. from the lower end the shaft is only $50 \mathrm{~mm}$. wide; the thickness is $25 \mathrm{~mm}$. The split extends a short distance above this height.

There are present three calcanea. One (Cat. No. 8242) belongs on the right side. Its total length is $155 \mathrm{~mm}$; the greatest height (at surface for articulation with the fibula), $68 \mathrm{~mm}$; the greatest thickness (just at the rear of the articular surface mentioned), $60 \mathrm{~mm}$. Another calcaneum belonging to the left side shows no important difference in size or form. A third one, somewhat damaged, is slightly smaller.

A right and a left astragalus in the collection differ only slightly in size. One (Cat. No. 8244), fitting pretty closely the calcaneum (Cat. No. 8242), had a length along the outer face of about $80 \mathrm{~mm}$; along the midline, a length of $60 \mathrm{~mm}$. The width along the front end is $58 \mathrm{~mm}$.

2. REMARKS ON CAMEL REMAINS FOUND IN SOME WIDELY DISTANT LOCALITIES, WITH DESCRIPTIONS OF TWO NEW SPECIES.

From Prof. Mark Francis, of College Station, Texas, an enthusiastic collector of vertebrate fossils, the writer has received a cervical vertebra, probably the fifth, which is of much interest. This bone, 
together with the distal end of a metapodial of a camel, was found by Doctor Francis in December, 1919, at Keeran Point, the eastern extremity of Victoria County. This locality is on Lavaca Bay, itself a prolongation northward of Matagorda Bay. In September there had been a violent storm in the Gulf, and the waves caused an enormous mass of the bluff to fall. Two farmers of the vicinity, L. Meyer and Edward Machac, gathered up some mastodon and elephant bones and teeth; and these they presented to the Agricultural and Mechanical College, at College Station. Later Doctor Francis visited the locality and picked up some camel remains. $\mathrm{He}$ informs the writer that the black surface soil is from 2 to 6 feet thick and barren of fossils. Below this is a cream-colored sand varying from 2 to 4 feet in thickness. In this were buried the bones. The writer is informed that the elevation of the surface there is about 20 feet. These facts appear to show that that bed of sand was laid down when camels were living there, and that was about the first third of the Pleistocene. The vertebra indicates a large animal, the length of the centrum being $145 \mathrm{~mm}$; in the dromedary, $160 \mathrm{~mm}$. Most of the neural arch and the zygapophyses are broken off; also the right transverse process and some of the left. Three views of it are presented (pl. 122, figs. 1-3). Figure 1 shows the bone as seen from below; figure 2, from the right; figure 3 , from in front. In the midline there is, in place of the conspicuous sharp ridge seen in the existing camels, a hardly perceptible elevation of the bone. The transverse processes at the anterior end of the vertebra are broken off, but they were evidently thicker and stronger than in the existing camels, and projected downward, outward, and forward, evidently somewhat beyond the end of the centrum. From the base of each process arise two ridges which pass backward. Of these the upper one expands into a broad wing and continues to the rear of the centrum. The lower one, prominent on the middle third of the lower face of the centrum, soon subsides and disappears on the hinder third. Where widest the bone must have had a breadth of about $140 \mathrm{~mm}$. In the dromedary it is only $95 \mathrm{~mm}$. The appearance of the lower face of this vertebra is very different from that of the dromedary.

The distal end of the metapodial resembles closely that of Camelops huerfanensis. The width across the articular end is $89 \mathrm{~mm}$., almost exactly that of the metapodial of the species last mentioned; and to it the specimens are provisionally referred.

With these camel remains there were found jaws, teeth, and tusks of a very large specimen of Elephas columbi, and a tooth of a species of a bunolophodont mastodon.

From Pittbridge, Brazos County, Doctor Francis has sent the writer an upper right hindermost molar and the distal end of a hinder cannon bone which were picked up along Brazos River. The tooth 
is well preserved and is not essentially different from the corresponding tooth from Denver here figured (pl. 116, fig. 6). The tooth and the cannon bone are referred to Camelops huerfanensis.

From Christmas Lake there is present a first, apparently anterior, phalangeal bone (Cat. No. 3821; pl. 123, fig. 2), which is to be compared with that of Camelops huerfanensis.

\section{Measurements of first phalanges of camels.}

\begin{tabular}{|c|c|c|}
\hline & $\begin{array}{l}\text { Camelops. } \\
\text { (No.3821). }\end{array}$ & $\begin{array}{l}\text { C.huer- } \\
\text { fanensis. }\end{array}$ \\
\hline Length on median plane. & 117 & 111 \\
\hline Fore-and-aft width of upper end, at epiphysiai suture.... & 40 & 41 \\
\hline Side-to-side width of upper articular surface............... & 45 & 42 \\
\hline Fore-and-aft diameter at middle of length $. . . \ldots \ldots \ldots \ldots \ldots . . . .$. & 24 & 25 \\
\hline Side-to-side width at middle of length............................... & 24 & 21 \\
\hline 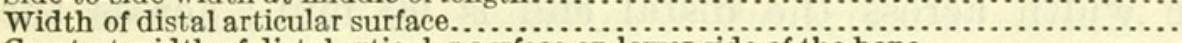 & 34 & 33 \\
\hline Greatest width of distal articular surface on lower side of the bone............ & & 32.5 \\
\hline
\end{tabular}

It is probable that this bone belongs to Camelops huerfanensis.

In the United States National Museum there are some remains of a camel which was found, associated with a horse, at Keams Canyon, Arizona. The parts seen are the upper end of a tibia, the lower end of the same tibia, the external malleolus, an astragalus, a calcaneum, a navicular, and the proximal end of a cannon bone, all of the same right limb. The total length of the calcaneum is $156 \mathrm{~mm}$., being close to that of Procamelus coconinensis from Anita, Arizona, described on page 622 . Instead, however, of finding an astragalus nearly as large as that of $P$. major, figured by Leidy and Lucas (a bone only slightly too large to fit the Anita calcaneum), one finds that the bone from Keams Canyon is much smaller. On the inner face the latter is $75 \mathrm{~mm}$. long; that from Florida, $92 \mathrm{~mm}$. The Keams Canyon animal belongs possibly to Camelops huerfanensis. The bones agree in every way with corresponding bones from Denver, Colorado, referred to C. huerfanensis.

It is interesting to find that remains of one or more very large camels have been found at various places in the elevated regions of the West. Matthew, in his list of vertebrates found at Christmas Lake ("Silver Lake"), Oregon, and Washtucna Lake, in southwestern Washington, ${ }^{5}$ mentions "teeth, foot bones, etc., of ? Camelops sp. max." In the National Museum there are some bones that were collected in 1882 at Christmas Lake by Dr. I. C. Russell, among which are the head of a humerus, the distal half or more of a left humerus, one of the distal divisions of a cannon bone, and a complete first phalangeal.

The head of humerus from Christmas Lake measures from front to rear of the articular surface $93 \mathrm{~mm}$; in the dromedary this

$\checkmark$ Bull. Amer. Mus. Nat. Hist., vol. 16, pp. 320, 321. 
measurement is $70 \mathrm{~mm}$. The distal half of the humerus from Christmas Lake (Cat. No. 3817) measures across the articular surfaces 96 $\mathrm{mm}$.; in the dromedary, $77 \mathrm{~mm}$. At a distance of $150 \mathrm{~mm}$. above the lower end of the inner condyle the fore-and-aft diameter is $68 \mathrm{~mm}$.; the side-to-side diameter, $59 \mathrm{~mm}$. The fore-and-aft width of the inner condyle is $108 \mathrm{~mm}$; in the dromedary, $86 \mathrm{~mm}$. The fossa for the olecranon is more deeply excavated than in the dromedary, and it is relatively narrower $-33 \mathrm{~mm}$.

There is in Russell's collection a complete right hinder cannon bone (U.S.N.M., Cat. No. 3824). The total length is $380 \mathrm{~mm}$; that along the outer border, $369 \mathrm{~mm}$. The width across the proximal articular surface is $70 \mathrm{~mm}$.; the fore-and-aft diameter at the middle of the length, ignoring the groove, $42 \mathrm{~mm}$; the side-to-side diameter, $40 \mathrm{~mm}$. The width across the distal end is $90 \mathrm{~mm}$; across the divisions, $42 \mathrm{~mm}$. The hinder face of the bone is occupied by a broad groove. It is doubtful whether this bone belongs to the largest camel found in that region. There is, however, another and larger right hinder cannon bone which lacks about the distal third. The fragment, measured along the outer border, is $290 \mathrm{~mm}$. long. The length originally was not far from $435 \mathrm{~mm}$. The width of the upper articular surface is $70 \mathrm{~mm}$.; the side-to-side diameter, at about the middle of the length of the bone, $45 \mathrm{~mm}$. The inner border of the hinder groove is higher than in the other bone just described. It is probably to be referred to the very large camel of the Christmas Lake region.

In a small lot of bones which were collected many years ago at Washtucna Lake, Washington, by the late Dr. George M. Sternberg, are three foot bones of a very large camel. These consist of a right astragalus, the distal end of an anterior cannon bone, a first phalange, and a second phalange. These parts may have all belonged to the same animal. On the catalogue they have the number 9717 . The astragalus is a large one. The length on the outer face is $96 \mathrm{~mm}$.; in the dromedary, $77 \mathrm{~mm}$. The width at the lower end is $70 \mathrm{~mm}$.; in the dromedary, $51 \mathrm{~mm}$. The cannon bone presents about 135 $\mathrm{mm}$. of the lower end. This bone is compared in the following table with the corresponding one of the dromedary Camelus dromedarius:

Measurements of anterior cannon bones in millimeters.

\begin{tabular}{|c|c|c|}
\hline 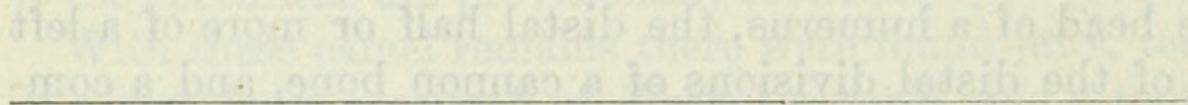 & $\begin{array}{l}\text { Oregon } \\
\text { camel. }\end{array}$ & $\begin{array}{c}\text { Drome- } \\
\text { dary. }\end{array}$ \\
\hline 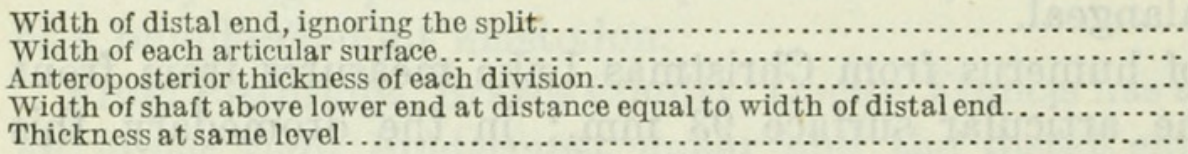 & $\begin{array}{l}108 \\
49 \\
45 \\
60 \pm \\
38\end{array}$ & $\begin{array}{l}90 \\
41 \\
42.5 \\
48 \\
24\end{array}$ \\
\hline
\end{tabular}


The first phalange (pl. 123, fig. 1) is compared with that of the dromedary.

Measurements of first anterior phalange in millimeters.

\begin{tabular}{|c|c|c|}
\hline 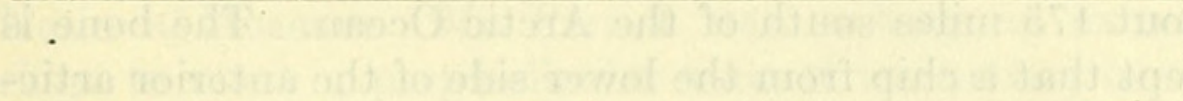 & $\begin{array}{l}\text { Oregon } \\
\text { camel. }\end{array}$ & $\begin{array}{l}\text { Drome- } \\
\text { dary. }\end{array}$ \\
\hline 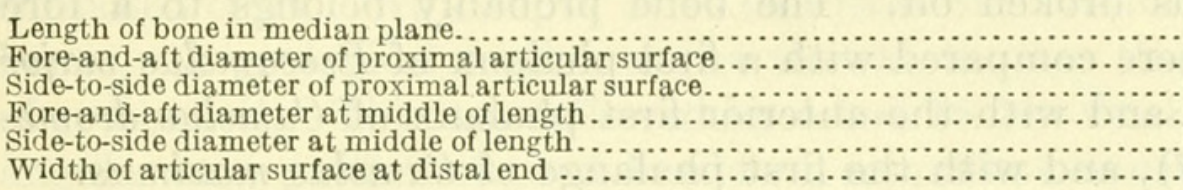 & $\begin{array}{l}115 \\
47 \\
58 \\
29 \\
35.5 \\
47\end{array}$ & $\begin{array}{l}94 \\
34 \\
41 \\
21.5 \\
21 \\
34\end{array}$ \\
\hline
\end{tabular}

This phalange resembles much that of the dromedary and differs from that of Camelops in the greater antero-posterior flattening of the bone and in the extension of the articular surface for the second phalange backward on the lower face of the bone. In this respect it agrees with the phalange here made the type of Camelus arctoamericanus. In each of these bones the articular surface extends backward about $43 \mathrm{~mm}$. The two bones hardly belonged to the same species. As will be seen on comparing the measurements they are of nearly the same length, but differ in other dimensions.

The second phalange is broad and flattened. The greatest length in the median plane is $81 \mathrm{~mm}$; the greatest width near the upper end, $51 \mathrm{~mm}$.; the greatest width in the lower half, $49 \mathrm{~mm}$.

It seems to the writer that the remains of the large camel from Christmas Lake and those from Washtucna Lake indicate a species different from any described species of Camelops and that this animal belonged to the genus Camelus. Following Doctor Matthew's suggestion it is named Camelus maximus. The first phalange from Washtucna Lake is made the special type specimen.

Type specimen.-A first phalange, No. 9717, U.S.N.M.

Type locality.-Washtucna Lake, Washington.

Type formation.-- Early Pleistocene.

Diagnosis.-Size large. Width of upper end of phalange equaling one-half of the length of the bone. Lower articular surface carried back on lower surface of this bone as in Camelus.

\section{CAMELUS ARCTOAMERICANUS, new species.}

Plate 119, fig. 12.

Type specimen.-A first phalange, No. 7713, U.S.N.M.

Type locality.-Old Crow River, near Alaska-Yukon boundary.

Type formation.--Pleistocene.

Diagnosis.-A large camel with broad phalanges, whose upper articular surface from side to side equals less than one-half of the length of the bone, and whose lower articular surface extends well backward on lower face. 
In the United States National Museum there is a first phalange of a camel which was found in 1912 by Copley Amory, close to the Alaska-Yukon boundary, at a distance of 50 miles above the mouth of Old Crow River. This locality is 100 miles north of the Arctic Circle and about 175 miles south of the Arctic Ocean. The bone is complete, except that a chip from the lower side of the anterior articular surface is broken off. The bone probably belongs to a fore limb. It is here compared with a first phalanx of Procamelus major from Florida, and with the anterior first phalanx of Camelus dromedarius (p. 607), and with the first phalange of Camelus maximus.

\section{Measurements of first phalangeal bone of camels.}

\begin{tabular}{|c|c|c|}
\hline 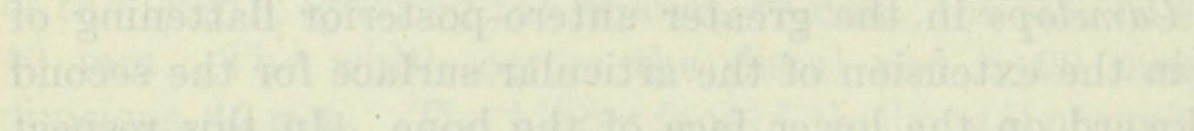 & $\begin{array}{l}\text { C. arcto- } \\
\text { ameri- } \\
\text { canus. }\end{array}$ & $\begin{array}{l}\text { Proca- } \\
\text { melus } \\
\text { major. }\end{array}$ \\
\hline Length of bone in median plane. & 110 & 118 \\
\hline Fore-and-aft diameter of proximal articular surface. & 40 & 44 \\
\hline Side-to-side diameter of proximal articular surface.. & 50 & 47 \\
\hline Fore-and-aft diameter at middle of length ............ & 25 & 27 \\
\hline Side-to-side diameter at middle of length .. & 33 & 28 \\
\hline idth of articular surface at distal end. & 44 & 37 \\
\hline
\end{tabular}

The measurements show that the phalanx of the arctic camel is larger in every way than that of the dromedary. It is more flattened, especially in the shaft, than either the dromedary or Procamelus major. The distal articulation is carried back on the hinder surface as it is in the dromedary. The hinder face of the shaft is flat and even somewhat excavated. It is a slenderer bone than that of $C$. maximus.

The relationships of this camel seem to be with Camelus rather than with Camelops and Procamelus; and to Camelus it is referred.

A notice of this discovery was published by Mr. J. W. Gidley in $1913^{6}$ but no systematic name has hitherto been applied to it.

With the camel bones above described from Christmas Lake were collected three astragali of horses, one of which is small, one of medium size, and one large; also a first, a second, and a third phalange of perhaps three horses; also a symphysis of the lower jaw of a small horse; also a first and a second phalange of a large deer, possibly a species of Sangamona; lastly, some fragments of a tusk of a proboscidean.

\section{ON A SMALL COLLECTION OF FOSSIL MAMMALS MADE IN CHELAN COUNTY, STATE OF WASHINGTON.}

In the United States National Museum there is a small collection of bones and teeth which were collected probably in 1897, by a settler named Parrish, on his place in the southwest quarter of section 23, 
township 23 north, range 19 east, near Wenatchee, Chelan County, Washington. An account of this find and the fossils themselves were sent to Dr. Henry Gannett, of the United States Geological Survey, by Mr. Fred G. Plummer. The correspondence is preserved in the National Museum. Mr. Parrish was making an excavation into a ridge to reach a perpendicular vein of travertine, in the search for supposed onyx. At a depth of 16 feet from the surface he found the bones. A geological section shows that at the top there was 1 foot of recent soil. This was followed by a bed 15 feet thick composed of angular and partly rounded bowlders, somewhat cemented together by calcite. Below this was an old soil, 4 feet in thickness, and in this were found the fossils. The soil was underlain by sandstone of unknown thickness.

Many of the bones are fragmentary and indeterminable even generically but the following list has been made out.

LIST OF FOSSILS AS DETERMINED.

Megalonyx jeffersonii?

Equus niobrarensis?

Odocoileus, species indeterminable.

Sangamona? species indeterminable.

Alces? species indeterminable.
Bison, species indeterminable. Marmota arrodens, new species. M. flaviventer.

Thomomys fuscus.

Lepus or Sylvilagus, species indeterminable.

There are too few species and their identification too uncertain to justify one in fixing too exactly the age of the deposit. The presence of Equus and of probably Sangamona appears to indicate a time not later than the Sangamon interglacial.

\section{MEGALONYX JEFFERSONII?}

A tooth, a second or third molar, of a species of Megalonyx, probably M. jeffersonii (Cat. No. 2658), is in the collection. The fragment is $42 \mathrm{~mm}$. long; the greater diameter is $20.5 \mathrm{~mm}$.; the shorter, $14 \mathrm{~mm}$. A section of the tooth resembles most that presented by Leidy. ${ }^{7}$

\section{EQUUS NIOBRARENSIS?}

A species of horse is represented by two lower left true molars-the first and the third (Cat. No. 10287). They are little worn. The first molar has the grinding surface $27.5 \mathrm{~mm}$. long and $17 \mathrm{~mm}$. wide, not including the cement. The third molar is $36 \mathrm{~mm}$. long and 16 $\mathrm{mm}$. wide in front. So far as the writer can see, these teeth are not distinguishable from those of the type of Equus niobrarensis.

7 Smiths. Contr. Knowl., vol. 7, pl. 16, fig. 14.

27177-21-Proc.N.M.vol.59-39 
ODOCOILEUS, species indeterminable.

Plate 117, fig. 1.

An indeterminable species of apparently this genus is represented by one of the distal pulleylike articular ends of a cannon bone. The diameter is $22 \mathrm{~mm}$. One lateral face has been gnawed by rodents. There is present also a first phalangeal bone which fits accurately against the trochlea just mentioned (pl. 117, fig. 1). It has exactly the length of a hinder first phalange of $O$. virginianus, but it is considerably slenderer. These bones have the catalogue number 10319 . The following are the comparative measurements:

Measurements of first phalanges of Odocoileus.

\begin{tabular}{|c|c|c|}
\hline$t_{0}$ & $\begin{array}{l}\text { O.sp. } \\
\text { indet. }\end{array}$ & $\begin{array}{l}\text { O. vir- } \\
\text { ginianus. }\end{array}$ \\
\hline Total length. & 56 & \\
\hline Fore-and-aft diameter at upper end & 19 & 21 \\
\hline Side-to-side diameter at upper end ............ & 15 & 17.5 \\
\hline Fore-and-aft diameter at middle of length.. & 14 & 14.5 \\
\hline Side-to-side diameter at middle of length......... & 10.5 & 13.2 \\
\hline Greatest width of distal articular surface... & 12.4 & 14,5 \\
\hline
\end{tabular}

SANGAMONA?, species indeterminable.

A deer larger than any existing species of Odocoileus and smaller than Cervus canadensis is indicated by a single bone, a left astragalus. The hinder half of a left astragalus (Cat. No. 9193) found at Cavetown, Maryland, and regarded as belonging to Sangamona fugitiva, has the same width; but the groove for the lower end of the tibia is deeper, and the inner ridge bounding this groove is thinner than in the astragalus from Washington. The side-to-side thickness of the bone taken at the middle of the length is close to $30 \mathrm{~mm}$. The astragalus of a specimen of Odocoileus virginianus is $43 \mathrm{~mm}$. long on the outer face, the width of the front end $29 \mathrm{~mm}$. The length in the fossil is $46 \mathrm{~mm}$; ; width in front $33 \mathrm{~mm}$. Here again in 0 . virginianus and likewise in $O$. hemionus, the inner ridge bounding the median groove is thinner than in the fossil. For the present this bone is referred to the genus Sangamona. This catalogue number is 10316 .

ALCES?, species indeterminable.

In the collection there is an epiphysis from the lower end of a cannon bone of a deer which had about the size of a moose. When compared with a corresponding part of the moose some minute differences are noted. These probably indicate a distinct species, possibly A. brevitrabilis or A. semipalmatus, both of which were described by Cope from parts of antlers found at Washtucna Lake, Oregon. Or the bone may belong to Cervalces. 
BISON, species indeterminable.

A species of Bison is indicated by one first phalange. Its proximal end is broken off. It is possible that it belongs to the preceding species. The catalogue number is 10318 .

MARMOTA ARRODENS, new species.

Plate 117, figs. $3-5,7,9$; plate 118, figs. 1, 3, 4 .

Type specimen.-Lower jaw, No. 2656, U. S. N. M.

Type locality.-Chelan County, Washington.

Type formation.-Pleistocene.

Diagnosis.-Size large. Lower incisors in adults equaling in breadth about two-fifths of the length of the row of molar teeth; its outer face, behind the enamel, furnished with a prominent ridge.

In the collection here considered there is a considerable number of teeth and bones of woodchucks. There appear to be present two species. One of these, represented by a lower jaw, probably also by other bones, was an unusually large marmot. As type of this supposed species are taken the right and left rami of the lower jaw, which bear the catalogue number 2656 of the United States National Musuem. Neither of these rami is complete, the better preserved one lacking the coronoid, condylar, and angular processes (pl. 117, figs. $3,4)$.

Inasmuch as the locality which furnished these bones lies within the area occupied by Marmota flaviventer and close to that occupied by subspecies of $M$. caligata, it is fair to make comparisons with the two species mentioned.

Measurements of teeth and lower jaws of species of Marmota.

\begin{tabular}{|c|c|c|c|}
\hline & $\begin{array}{l}\text { M. arro- } \\
\text { dens. }\end{array}$ & $\begin{array}{l}\text { M. flavi- } \\
\text { venter. }\end{array}$ & $\begin{array}{l}\text { M. cali- } \\
\text { gata. }\end{array}$ \\
\hline 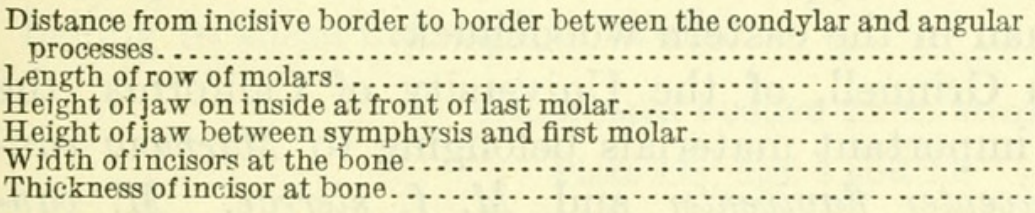 & $\begin{array}{l}64 \\
20 \\
16.5 \\
14 \\
8.1 \\
5\end{array}$ & $\begin{array}{l}62 \\
20 \\
15 \\
12 \\
6.5 \\
4\end{array}$ & $\begin{array}{l}64 \\
22 \\
15.5 \\
12.5 \\
7 \\
4\end{array}$ \\
\hline
\end{tabular}

Besides the ridges and grooves of various widths usually found on the enamel of the incisors of the species of Marmota, there is in $M$. arrodens, about halfway between the hinder edge of the enamel and the hinder border of the tooth, a prominent ridge. In front of it is a broad groove; behind it a narrower one. On the enamel there are distinct remains of the original pale orange color.

There are various limb bones which may or may not belong with the jaw just described. They may, indeed, belong to the same individual. In the jaw the molar teeth are all worn down smooth, while 
in the limb bones the epiphyses are not yet ankylosed to the shafts. However, in a skeleton of $M$. monax at hand, the bones are in about the same stage and the molar teeth are worn down nearly as much as in the jaw of $M$. arrodens. The writer is inclined to believe that the limb bones belong with the jaw. They are here to be compared with a skeleton of M. monax (Cat. No. 20765) found near Washington, District of Columbia. These bones are illustrated alongside those of the fossil. On the plate cited the humerus of M. arrodens is shown by figure 5 ; that of $M$. monax by figure 6 .

Measurements of humeri of Marmota.

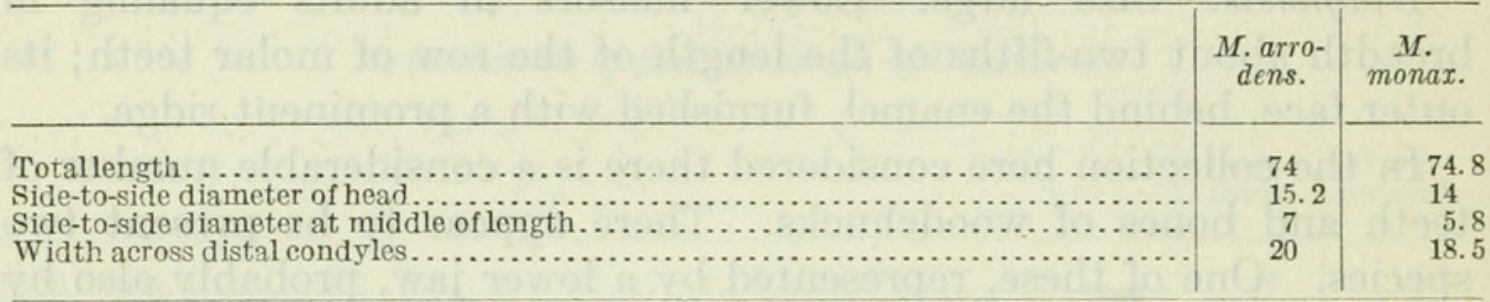

Figures 7 and 8 of plate 117 show, of the natural size, the right ulna of the fossil and that of $M$. monax; while figures 9 and 10 present views of the right radii of the same individuals, respectively. The ulna of the fossil has lost its distal epiphysis. Of the left femur supposed to belong with the bones of the fore-limb there is present only the upper half (pl. 118, fig. 1). It will be seen at once that the fossil femur is a far stouter bone than that of $M$. monax (pl. 118, fig. 2); and it was probably little, if any, longer than the other femur.

Three tibia, one of the right side of $M$. monax and both right and left of the fossil, are shown on plate 118; figures 3 and 4 are those of the fossil bones; figure 5 that of the recent skeleton. The right tibia of the fossil is $81 \mathrm{~mm}$. in total length; that of $M$. monax only one-half millimeter longer. Here again the recent bone is seen to be much slenderer. In the fossil the upper half of the hinder face is much more deeply excavated than in the eastern woodchuck.

From Dr. Joseph Grinnell, of the University of California, the writer has received important materials belonging to Marmota vancouverensis, $M$. flaviventer flaviventer and $M$. $f$. sierrae. $M$. vancouverensis is a very large species, one humerus measuring in length $93 \mathrm{~mm}$., the ulna $94 \mathrm{~mm}$. The humerus of M. arrodens, $74 \mathrm{~mm}$. long, is a relatively stouter bone than that of $M$. vancouverensis, especially proximally. On comparison with a humerus $82 \mathrm{~mm}$. long of $M$. vancouverensis, it is found that the side-to-side diameter just above the insertion of the latissimus muscle is $9.5 \mathrm{~mm}$.; in M. arrodens, $11 \mathrm{~mm}$. Where the bones are narrowest below the deltoid ridge the diameters are little different, that of $M$. arrodens being slightly less. The 
greatest width of the lower end of the bone is $22.5 \mathrm{~mm}$. in M. vancouverensis; in $M$. arrodens, $20 \mathrm{~mm}$.

The ulna of $M$. arrodens originally had a length of $83 \mathrm{~mm}$. and the humerus is $74 \mathrm{~mm}$. long. In M. vancouverensis the ulna is only 2 or 3 $\mathrm{mm}$. longer than the humerus. The bones of $M$. arrodens are stouter than the corresponding ones of $M$. vancouverensis. In an ulna of the latter $77 \mathrm{~mm}$. long, the depth in front of the coronoid process is 8 $\mathrm{mm}$.; in $M$. arrodens, $9 \mathrm{~mm}$. In a radius of $M$. vancouverensis the least diameter at the middle of the length is $4 \mathrm{~mm}$.; in $M$. arrodens, $5 \mathrm{~mm}$. The ulna and radius of the latter are more bent than in the other species.

The humerus, ulna, and radius of $M$. arrodens have been compared with the same bones of $M$. flaviventer flaviventer and $M$. f. sierrae, from various localities in California, sent by Doctor Grinnell. Both forms are smaller than $M$. arrodens and considerably smaller than $M$. vancouverensis. These two forms of $M$. flaviventer differ from M. arrodens in the same way as does M. vancouverensis.

\section{MARMOTA FLAVIVENTER (Audubon and Bachman).}

Plate 118, figs. 6-8.

This species appears to be represented in the collection by the rear of a skull preserving the basioccipital, the bullae, the petrosals, and the supraoccipital; also by the remainder of possibly the same skull from just behind the orbits to the front of the maxilla (pl. 118, figs. 6,7$)$. These have the catalogue number 2655 . The nasals are missing; also the incisor teeth and three of the molars of the right side. On comparison with skulls of $M$. flaviventer'no differences are noted. The molar teeth are little worn. The interorbital portion of another skull (Cat. No. 2657) is also represented (pl. 118, fig. 8). In this there is a complete postorbital process. Two right rami of lower jaws, or rather parts of them, with some little worn teeth, may belong to these incomplete skulls.

THOмомYS FUSCUS (C. H. Merriam).

Plate 118, figs. 9 and 10.

This species is represented by a single incisor and by the anterior half of a skull, which contains both incisors, but lacks all the molars and both nasal bones. On comparison with a skull of $M$. fuscus from that region no differences are observed. The incisors retain much of their original color.

LEPUS OR SYLVILAGUS, species indeterminable.

A single right ramus of a rabbit is in the collection. It has about the size of the corresponding part of Sylvilagus nuttallii. 
4. DESCRIPTIONS OF THREE SUPPOSED NEW SPECIES OF RODENTS OF PLEISTOCENE AGE, ONE FROM NEBRASKA, ONE FROM OREGON, AND ONE FROM TEXAS.

Through the liberality of the American Museum of Natural History, New York, the writer has been permitted to study the collections of vertebrate remains of Pleistocene age which that institution possesses. Among the remains sent are parts of the Cope collection, made at different localities; also some specimens collected by expeditions sent out by the American Museum itself.

Of especial importance is the large collection made by Mr. Barnum Brown in the Conard fissure, in Newton County, Arkansas, in 1903 and 1904. Of interest, too, is a small collection made by Mr. Brown in a cave at Anita, Coconino County, Arizona, in 1904. In the study of the materials mentioned the writer has found what appear to be three new species of Glires. The following are the species:

THOMOMYS SCUDDERI, new species.

Plate 120, figs. 1-4.

Type specimen.- Skull with the incisors and molars, but lacking most of the part behind the frontals; the lower jaw with its teeth; a few vertebrae; the pelvis and some limb bones. No. 8596, American Museum of Natural History, New York; a part of the Cope collection.

Type locality.-Christmas Lake, Oregon.

Type formation.-Pleistocene.

Diagnosis.-Animal of medium size. Lower outline of rostrum straight to near the incisors. The latter grooved and incurved somewhat more than in T. bottae leucodon, but not projecting so far beyond the bone. Interorbital space flat, the ridges inconspicuous, and forming a lyriform figure on the frontals.

In studying these fossil remains the species that first suggested itself for comparison is that now living in the region of Christmas Lake, Thomomys quadratus Bailey. ${ }^{8}$ A slight examination shows, however, that the fossil does not belong to T. quadratus. A comparison with materials in the United States National Museum and in the Biological Survey has led the writer to regard the remains as being somewhat closely related to T. bottae leucodon.

This subspecies ranges to-day from Cape Saint Lucas to Grants Pass, in southwestern Oregon. It has incisors which are slenderer than those of the fossil. A specimen in the National Museum (Mamm. Cat. No. 4783) measures, from the rear of the frontals to the incisive border, in front of the incisors, $26 \mathrm{~mm}$. This is the same as in the fossil skull. The interorbital space in the former is $7 \mathrm{~mm}$. wide; in the fossil, $7.5 \mathrm{~mm}$. the width of the rostrum in the former is $7 \mathrm{~mm}$.; in 
the fossil, $8 \mathrm{~mm}$. The interorbital space of the former is transversely concave; in the latter it is flat. The nasals of the fossil were considerably wider than those of $T$. bottae leucodon.

The lower jaw has the same length as that of the specimen of T. b. leucodon, No. 4783, mentioned above. In the latter the incisors project beyond the extreme end of the jaw $10 \mathrm{~mm}$; in the fossil they project only $7.4 \mathrm{~mm}$.

The fossil skull appears to resemble still more closely that of T. bottae nigricans, a form inhabiting the region about San Diego, California. In this again the incisors project beyond the bone more than in the fossil, and they appear to be somewhat more strongly curved downward. The interorbital space is $7 \mathrm{~mm}$. wide and transversely concave. The ridges form the same lyriform figure as in the fossil. The nasals overlap the frontals more than they did in the fossil.

The species here described is named in honor of Mr. N. P. Scudder, librarian at the United States National Museum, to whom the writer has been greatly and for a long time indebted for assembling the literature that he has required in his studies.

CYNOMYS NIOBRARIUS, new species.

Plate 122, fig. 7.

Type specimen.-A part of the skull which presents the palate and its teeth; part of the interorbital space; and the bases of the zygomatic arches (No. 2715, American Museum of Natural History, New York).

Type locality.-Niobrara River, near Grayson, Nebraska.

Type formation.-Sheridan beds of the Pleistocene.

Diagnosis.-Allied to $C$. leucurus, but appears to have differed in being larger and in having a broader and deeper groove for the anterior branch of the masseter muscle.

The label on this specimen states that it was collected by the American Museum expedition in 1897. It is a thoroughly mineralized fossil and was evidently buried in sand. The third milk molar is present on the left side. On the right side it is missing; but deep in the socket is seen the uncut third premolar. The next tooth behind on each side is probably the fourth milk molar. All three molars on each side are present.

The bases of the zygomatic arches are somewhat injured, but they show that the anterior border of the upper root approached the premaxilla as it does in $C$. leucurus, and not nearly at a right angle, as it does in $C$. ludovicianus. The lower border of the anterior root of the zygomatic arch ends abruptly opposite the first molar, as in 
C. leucurus. In C. ludovicianus the border is prolonged backward as a distinct ridge as far as the second or third molar. In the fossil it does not descend so close to the alveolar border as it does in both of the existing species just named. The broad groove running upward and forward in front of the anterior root of the zygomatic arch is deeper and broader than in C. leucurus, especially anteriorly, being more like that of $C$. ludovicianus. Along the middle of the palate there is a sharp and prominent ridge, highest in front. This is present in $C$. leucurus, sometimes becoming nearly as prominent as in the fossil.

Enough of the interorbital space is left to show that the width was at least $11.5 \mathrm{~mm}$. This width is very variable in $C$. leucurus.

Cynomys niobrarius was probably larger than C. leucurus, since the tooth row, measured on the alveolar border, is very close to 17 $\mathrm{mm}$. long, and would certainly have exceeded this after the replacement of the milk molars by the premolars. The three molars occupy $11.5 \mathrm{~mm}$. of the alveolar border. No specimen of C. leucurus showed quite so large a molar row. The species now occupying that region is the typical C.ludovicianus. C. leucurus inhabits the mountainous regions of Wyoming, Colorado, and New Mexico. ${ }^{9}$

CITELLUS TAYLORI, new species.

Plate 120, fig. 7.

Type specimen.-A left ramus of a lower jaw, with the premolar, the molars, and a part of the incisor. Amer. Mus. Nat. Hist., New York.

Type locality.-Probably somewhere in the vicinity of San Diego, Texas.

Type formation.-Pleistocene.

Diagnosis.-First and second molars wider than long. The anterior transverse crest of moderate height. The premolar as long as wide; the cusps of its anterior crest with a shallow notch between them.

The type of this supposed species is a part of the Cope collection in the American Museum of Natural History. It is labeled as having been collected by W. Taylor, of San Diego, Texas, who was one of Cope's collectors in that region. The jaw is further labeled as having been found in the "elephant beds." The jaw and teeth seem to resemble most those of Citellus townsendi-a species now living in Oregon, Wyoming, and California. The molar teeth have the same short, broad form, and the jaw itself is hardly different. The anterior crest of each tooth is, however, not so high as in that species and not so abruptly steep on its hinder face. The premolar of $C$. townsendi and of various other species examined is shorter than wide; also in

\footnotetext{
${ }^{\circ}$ Hollister, N. A. Fauna, No. 40, p. 24.
} 
this species and others there is an infold of the enamel on the inner part of the front face of the premolar, or a deep notch between the cusps. Nothing of this is seen in the fossil. The teeth have suffered but little wear, and yet a very little more would have produced one straight loop of enamel across the front of the grinding surface of the anterior premolar.

The length of the tooth row is $10 \mathrm{~mm}$. The distance from the mental foramen to the rear of the condyle is $22 \mathrm{~mm}$. The height of the ramus at the second molar is $6.5 \mathrm{~mm}$.

5. COLLECTION OF FOSSIL MAMMALS MADE AT ANITA, COCONINO COUNTY, ARIZONA.

From Mr. Barnum Brown, of the American Museum of Natural History, New York City, the writer has received a small collection of fossil mammals which had been made at Anita, Arizona. The greater part of these specimens had been secured by Mr. B. C. Bicknell in 1901; another part was collected by Mr. Brown himself in 1904. The portion gathered by Mr. Bicknell was the property of the Arizona School of Mines, at Tucson, and had been sent for examination in 1904 to Mr. Brown by the director, Dr. W. P. Blake. Other pressing duties prevented Mr. Brown from completing his studies of these remains. From Mr. Brown's notes it appears that the fossils were found at the Val Verde Copper Mines, at Anita, a station on the Grand Canyon branch of the Santa Fe Railroad, 40 miles north of Williams and 20 miles south of the Grand Canyon. The collecton has become the property of the United States National Museum through exchange.

The fossils were discovered in a fissure in a Carboniferous limestone. This fissure was entered in the making of some prospect holes by the workmen of the copper company. The bones appear to have been buried in a deposit of sand about 7 or 8 feet thick, lying on the bottom of the cave or fissure. They are in a fine state of preservation, but are mostly pretty badly broken up. Mr. Brown's examination of the collection resulted in the recognition of remains of horses, camels, rabbits, woodchucks, packrats, pocket gophers, and squirrels. Being engaged in other investigations he did not have the time to study the remains and he generously put them into the hands of the writer. Unfortunately other lines of work have prevented a consideration of them until recently. Most of Mr. Brown's general determinations have been confirmed. In addition, a few other forms have been recognized, among them a hyaena-like animal. In case this determination shall be confirmed an important addition will have been made to our extinct fauna. Cope believed that the genus Borophagus. belonged to the Hyaenidae, but it is now arranged among the Canidae. 
LIST OF SPECIES FOUND AT ANITA.

EQUIDAE.

Equus occidentalis? Equus giganteus?

TAGASSUIDAE.

Mylohyus? Species indeterminatable.

CAMELIDAE.

Procamelus coconinensis, new species. Procamelus longurio, new species.

Antilocapra americana?

BOVIDAE.

SCIURIDAE.

Marmota arizonae, new species. Citellus tuitus, new species.

Neotoma cinerea. CRICETIDAE.

LEPORIDAE.

Lepus benjamini, new species. Brachylagus browni, new species. MUSTELIDAe.

Taxidea robusta, new species.

CANIDAE.

Canis nubilus? Canis latrans?

HYAENIDAE.

Chasmaporthetes ossifragus, new genus, new species.

Family EQUIDAE.

An examination of the bones belonging to the genus Equus shows that two species are represented-one of medium size, one very large. The former is referred to Equus occidentalis, the latter provisionally to Equus giganteus.

EQUUS OCCIDENTALIS Leidy.

Plate 118, fig. 11; plate 124, fig. 1.

To this species are referred the proximal end of a left third metacarpal bone (Cat. No. 10131); an upper second premolar (Cat. No. 10132); an upper right third molar (Cat. No. 10133), and some fragments of other upper teeth; a lower hindermost molar (Cat. No. 10134); some fragments of other upper and lower teeth (Cat. No. 10135); and an incisor (Cat. No. 10136). The fragment of metacarpal is only $65 \mathrm{~mm}$. long. This bone and the others here considered are compared with those of a skeleton of a horse in the National Museum (Cat. No. 174960). In this recent horse the sideto-side diameter of the upper end of the metacarpal is $55 \mathrm{~mm}$; in the fossil bone this diameter is $50 \mathrm{~mm}$. The facet for the cuboid bone is considerably smaller in the fossil bone than in that of the recent horse. 
The second right premolar is a nearly unworn tooth. In order to get an adequate view of the enamel, the tooth was sawn across, about 1 inch below the grinding surface. The end of the proximal section was polished and a view of it is presented (pl. 118, fig. 11); but this is the reverse of the one that would be shown on the grinding surface of a tooth of that side. The upper right hindermost molar is worn down to about $45 \mathrm{~mm}$. of the root. The length of the crown along the outer border is $33 \mathrm{~mm}$.; the width is $24 \mathrm{~mm}$.; the fore-andaft diameter of the protocone, $17 \mathrm{~mm}$. Besides the unusual length of the protocone it is thin and flat, differing in these respects greatly from that of the tooth figured by Gidley. ${ }^{10}$ The postprotoconal valley, too, has a deep inlet near its head. The width and thinness of the protocone is shown in two fragments of upper teeth. The hindermost lower molar had just begun to wear. The height is 85 $\mathrm{mm}$; the length at half of the height, $38 \mathrm{~mm}$; the thickness in front, $15 \mathrm{~mm}$. A fragment of an upper tooth (Cat. No. 10215), somewhat worn, is $80 \mathrm{~mm}$. high and considerably curved. A fragment of a little-worn lower tooth (Cat. No. 10216) is $100 \mathrm{~mm}$. high. A little-worn and deeply cupped incisor (Cat. No. 10217) is $20 \mathrm{~mm}$. wide. It appears to be safe to refer these teeth to Equus occidentalis. There are in the collection a few vertebrae and fragments of other bones of Equus, some of which may belong to this species. It is not at all improbable that the remains here described will prove eventually to belong to an undescribed species.

EQUUS GIGANTEUS? Gidley.

Plate 118, fig. 12; plate 124, fig. 2-3.

The larger horse of the collection is referred with doubt to $\mathrm{Mr}$. J. W. Gidley's Equus giganteus ${ }^{11}$ found in southwestern Texas and based on a tooth which had been referred by Cope ${ }^{12}$ to E. crenidens. The reason for this identification of the Anita materials is admitted by the writer to be the evident large size of the horse. There are present an upper right hindermost molar (Cat. No. 14361 Amer. Mus. Nat. Hist.) and some fragments of teeth which appear not to belong to Equus occidentalis; but these fragments (Cat. No. 10137) present no special resemblance to the tooth which forms the type of E. giganteus. Two of the fragments are here illustrated. Figure 12 of plate 118 presents a part of the anterior fossette of an upper grinding tooth. The section shown belongs about an inch above the root of the tooth. The distance across this fossette is $16.2 \mathrm{~mm}$; in a large domestic horse the corresponding distance is $15 \mathrm{~mm}$. Figure 3 of plate 124 gives a view of the postprotoconal valley of an upper tooth,

${ }^{10}$ Bull. Amer. Mus. Nat. Hist., vol. 14, p. 115, fig. 10.

11 Idem, p. 137, fig. 27.

12 Amer. Naturalist, vol. 19, p. 1208, pl. 37, fig. 4. 
possibly of the same one shown in figure 2 of plate 124 . The double inlet at the head of the valley is unusual.

In the part of the collection from this place made by Mr. Barnum Brown for the American Museum of Natural History is an upper right third molar (plate 124, fig. 2). It is worn down to $25 \mathrm{~mm}$. from the root. The length is $36 \mathrm{~mm}$. along the outer face; the width is $30 \mathrm{~mm}$. The fossettes are wide and the enamel simple. There is an inlet at the head of the postprotoconal valley. The catalogue number is 14361 . It is referred to the larger of the two horses found at Anita.

Among the bones referred with reservations to this species are most of those of the left tarsus (Cat. No. 10138) in their natural relations - a condition that shows that these parts were held together by their ligaments when they reached the fissure. All of the bones of this tarsus are present, except the consolidated internal and middle cuneiforms. As illustrating the size of these parts, the distance from the rear of the calcaneum to the front of the external cuneiform, $161 \mathrm{~mm}$., may be compared with that of the horse of medium size already mentioned. This comparison shows that in case all other parts were proportionately large, the extinct species was fully onefifth higher than the recent one.

The following measurements are given of some of the individual bones of these tarsi.

Measurements of tarsal bones.

\begin{tabular}{|c|c|c|}
\hline 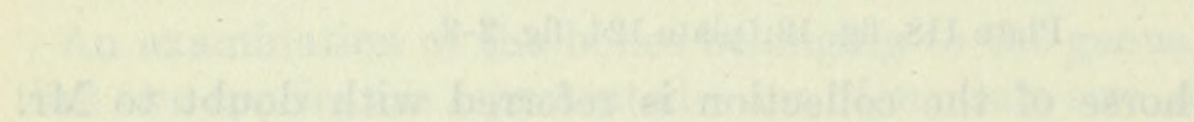 & $\begin{array}{c}\text { E. gi- } \\
\text { ganteus. }\end{array}$ & $\begin{array}{c}\text { No. } \\
\text { 174960, } \\
\text { U.S.N.M. }\end{array}$ \\
\hline 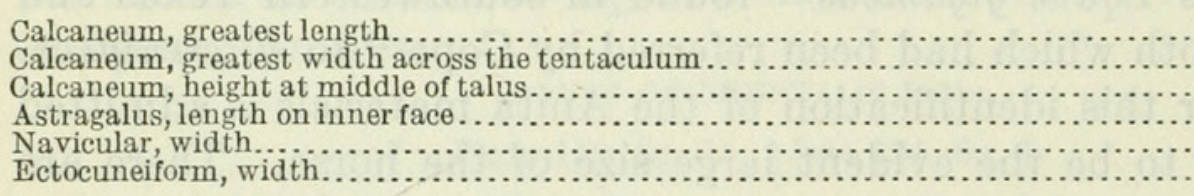 & $\begin{array}{r}135 \\
54 \\
50 \\
74 \\
62 \\
57\end{array}$ & $\begin{array}{r}117 \\
50 \\
43 \\
64 \\
56 \\
50\end{array}$ \\
\hline
\end{tabular}

In the collection is about the upper half of a right third metatarsal (Cat. No. 10139). Unfortunately, the upper end is damaged so that the side-to-side diameter can not be determined. The foreand-aft diameter is $50 \mathrm{~mm}$.; in the recent horse, $44 \mathrm{~mm}$. At a distance of $90 \mathrm{~mm}$. below the upper end the side-to-side diameter of the shaft is $40 \mathrm{~mm}$.; the fore-and-aft, $35 \mathrm{~mm}$. In the recent horse at hand these diameters are respectively $32 \mathrm{~mm}$. and $33 \mathrm{~mm}$. There are present two distal ends of third metapodials (Cat. No. 10140); but the writer can not convince himself that either of them belonged to the hinder limb. Three splint bones are in the collection (Cat. No. 10141), with the distal ends missing. The diameters of the upper ends are about one-third greater than in the recent horse used for 
comparison. A part of the shaft of a radius (Cat. No. 10142), 185 $\mathrm{mm}$. long, has a breadth of $47 \mathrm{~mm}$. at about the middle of the whole bone. A nearly complete left third metacarpal (Cat. No. 10143) is present.

The following comparative measurements are given:

Measurements of third metacarpals.

\begin{tabular}{|c|c|c|}
\hline & $\begin{array}{c}\text { E. gi- } \\
\text { gantous. }\end{array}$ & $\begin{array}{l}\text { No. } \\
174960 \\
\text { U.S. } \\
\text { N. M. }\end{array}$ \\
\hline 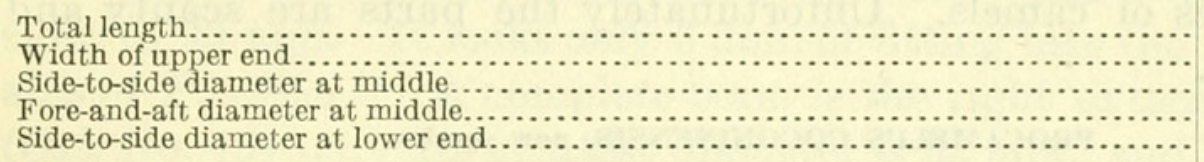 & $\begin{array}{r}268 \\
61 \\
40 \\
32 \\
55\end{array}$ & $\begin{array}{r}246 \\
56 \\
32 \\
27 \\
54\end{array}$ \\
\hline
\end{tabular}

It will be seen that the fossil bone is only about one-tenth longer than the recent one. It is not at all improbable that it belonged to the smaller horse, but the metacarpal described as representing that horse is only $50 \mathrm{~mm}$. wide above.

A first phalangeal bone (Cat. No. 10144) of the third digit has a length, in the median plane, of $88 \mathrm{~mm}$; that of the hinder bone of the recent horse being $77 \mathrm{~mm}$. The width at the upper end is 63 $\mathrm{mm}$.; that of the recent horse, $57 \mathrm{~mm}$. It is not larger than corresponding bones of supposed Equus pacificus from Christmas Lake, Oregon. A second phalange (Cat. No. 10146) is $55 \mathrm{~mm}$. wide at its lower end; that of the recent horse, $44 \mathrm{~mm}$. A hoof phalange (Cat. No. 10147) is $78 \mathrm{~mm}$. wide. The latter bone appears to belong to a hinder limb. In the part of this collection that was made for the American Museum of Natural History there are a second and a third - phalangeal which appear to belong to a fore limb. These have that museum's catalogue number, 14362. The second phalange is $63 \mathrm{~mm}$. wide at the upper end; $55 \mathrm{~mm}$. wide at the lower end. The hoof phalange is $84 \mathrm{~mm}$. wide. This phalange is more broadly rounded than that supposed to belong to the forefoot.

\section{MYLOHYUS ? species indeterminable.}

In the collection there is a fragment (Cat. No. 10153) of the upper end of the ankylosed lower arm bones of the right side. The olecranon process is likewise broken off. The whole fragment is only $80 \mathrm{~mm}$. long, and it extends $65 \mathrm{~mm}$. below the greater sigmoid cavity. The width of the radius in this cavity is $29 \mathrm{~mm}$. At the lower end the fragment has a width of $26.5 \mathrm{~mm}$; ; a thickness of $17 \mathrm{~mm}$. On the hinder face of the fragment, at a distance of $42 \mathrm{~mm}$. below the front of the greater sigmoid cavity, is a foramen. A specimen of Platygonus from a fissure near Cumberland, Maryland, measures $160 \mathrm{~mm}$. from 
the front of the sigmoid cavity to the lower end of the radius. The articular surface of the upper end of the radius is $35.5 \mathrm{~mm}$. wide. From the articular surface to the foramen corresponding to the one mentioned above the distance is $33 \mathrm{~mm}$. These measurements appear to indicate that the forearm of the fossil animal was both longer and slenderer than that of Platygonus. The genus Mylohyus appears to be indicated.

\section{Family CAMELIDAE.}

In the collection being considered the writer recognizes remains of two species of camels. Unfortunately the parts are scanty and fragmentary.

PROCAMELUS COCONINENSIS, new species.

Plate 122, figs. 4-6; plate 123 , fig. 5 .

Type specimen.-An upper left second molar (Cat. No. 10154).

Type locality.-Coconino Forest plateau, Arizona.

Type formation.-Early Pleistocene.

Diagnosis.-The type molar resembles that of $P$. major, but has the outer crescents much thicker at the same level.

Of a very large camel there are present the greater part of an upper molar tooth and some foot bones.

The tooth (pl. 122, figs. 4, 5) is taken to be the upper left second molar. The writer has the advantage of having for comparison the materials figured in the paper by Leidy and Lucas on some fossil remains found in the Alachua clays, at a point 10 miles south of Archer, Levy County, Florida. ${ }^{13}$

The tooth from Anita has lost nearly the whole of the inner crescent of the front lobe and a part of that of the hinder. It is worn down pretty well, the height of the lobes being about $20 \mathrm{~mm}$. The length of the crown at the base is $36 \mathrm{~mm}$.; at the grinding surface, along the midline, $38 \mathrm{~mm}$. The width of the hinder lobe appears to be $33 \mathrm{~mm}$.; that of the front lobe can not be determined. When comparison is made with the upper right second molar figured in the paper cited (pl. 17, fig. 4) some differences are observed. The length of the two crowns, taken at the same level, is almost exactly the same. The length of the hinder lobe in the Florida tooth is about $2 \mathrm{~mm}$. less. The styles and ribs on the outer faces of the teeth are hardly different, and the minute differences might be those of individual teeth or of individual animals. There appear to be, however, important differences in the widths of the outer crescents (paracone and metacone), those of the Arizona animal being much thicker. Inasmuch as the crowns of the two teeth compared have quite exactly the same height the differences in width must be due to actral differ-

13 Trans. Wagner Free Inst., vol. 4, pp. i-xiv; 15-61, pls. 1-19. 
ences in thickness. Measuring from the pillar on the outer face of the anterior crescent to its inner wall the distance is $17 \mathrm{~mm}$.; in $P$. major it is only $14 \mathrm{~mm}$. One must measure from nearly the bottom of the fossette in order to get a width of $17 \mathrm{~mm}$. The hinder crescent of the Arizona specimen at the worn surface is $14 \mathrm{~mm}$. wide; that of $P$. major only $9 \mathrm{~mm}$. It is only at the bottom of the fossette that the width is $14 \mathrm{~mm}$. These differences appear to be indication of specific difference.

Of a large camel there are some fragments of limb bones. One of these is part of the distal end of a right tibia (Cat. No. 10156). An estimate shows that the width of the lower end of this bone was close to $93 \mathrm{~mm}$. It lacks only $5 \mathrm{~mm}$. of fitting into the right astragalus of $P$. major. ${ }^{14}$ A complete bone is the right external malleolus (Cat. No. 10157). Its greatest diameter is $52 \mathrm{~mm}$., and it fits closley against the right calcaneum. This calcaneum (Cat. No. 10158) belonged to an animal that had not reached its greatest size, inasmuch as the hinder epiphysis is missing. The length is now $146 \mathrm{~mm}$. The same bone of the dromedary has a total length of $141 \mathrm{~mm}$. The fossil calcaneum must have been originally about $165 \mathrm{~mm}$. long. The height at the external malleolus is $75 \mathrm{~mm}$; in the dromedary, $61 \mathrm{~mm}$. A right navicular (Cat. No. 10159) has its greatest diameter $56 \mathrm{~mm}$.; in the dromedary this diameter is $48 \mathrm{~mm}$. The fossil bone fits quite exactly on the astragalus of $P$. major.

There is in the collection a part of the shaft of a hinder cannon bone (Cat. No. 10162), the length of the fragment being $185 \mathrm{~mm}$. Proximally it reaches about the middle of the shaft; distally a little beyond the top of the split. The fore-and-aft diameter of the upper end is $45 \mathrm{~mm}$; the side-to-side diameter, $40 \mathrm{~mm}$. In the dromedary these diameters are, respectively, $34 \mathrm{~mm}$. and $30 \mathrm{~mm}$.

A fragment (Cat. No. 10175) which presents the distal articular end of one of the divisions of a cannon bone is $50 \mathrm{~mm}$. wide. In the dromedary the width of the corresponding part of the anterior cannon bone is $41 \mathrm{~mm}$; the width of this part of a metapodial of Camelops huerfanensis, $40 \mathrm{~mm}$. This bone has the size and general appearance of the same part in the large camel which the writer describes in this paper as Camelus maximus. When closely examined, however, differences are seen. The grooves alongside of the guiding keels are deeper in $C$. maximus. While the side-to-side widths of the articular surface is the same in the two bones, the foreand-aft thickness in C. maximus is $45 \mathrm{~mm}$.; in the Arizona bone it is $50 \mathrm{~mm}$. This bone may belong to a very large individual of Procamelus coconinensis or it may represent an otherwise unknown form.

A practically complete first phalange (Cat. No. 10163), probably an anterior one, is present (pl. 122, fig. 6). The length in the median

1f Leidy and Lucas, pl. 18, fig. 1. 
plane is $106 \mathrm{~mm}$; the width across the proximal articular surface is $46 \mathrm{~mm}$.; that across the distal surface, $38 \mathrm{~mm}$. At the middle of the length the fore-and-aft diameter is $24 \mathrm{~mm}$.; the side-to-side diameter, $27 \mathrm{~mm}$. The bone resembles closely the corresponding one of Procamelus major..$^{15}$ The former is, however, a slightly stouter bone, as may be seen in comparing the measurements just given with those of the table on page 608. On the underside of the distal end the lower articular surface ascends a height equal to one-third the total length of the bone; in P. major, only 0.27 of the length. The fore-and-aft width of the upper articular surface in $P$. major equals $44 \mathrm{~mm}$.; in the bone from Arizona, only $39 \mathrm{~mm}$. The fore-and-aft thickness of the distal end of the bone in $P$. major is $36 \mathrm{~mm}$.; in the other bone, $32 \mathrm{~mm}$. These differences appear to be of specific value.

There is present in the collection a first phalange (Cat. No. 10177), which appears to belong to the hinder foot of this species (pl. 123, fig. 5). It is that of a rather young animal, inasmuch as the epiphysis is missing from the upper end. The bone is there somewhat damaged. Its original length was very close to $85 \mathrm{~mm}$. The sideto-side diameter at the middle of the length is $21 \mathrm{~mm}$.; the fore-andaft, $20 \mathrm{~mm}$. The width of the distal articular surface is $25 \mathrm{~mm}$. The hinder face is concave both up and down and from side to side.

There is present the greater part of one second phalange, probably belonging to a front foot (Cat. No. 10165). The upper articular surface is $43 \mathrm{~mm}$. wide.

\section{PROCAMELUS LONGURIO, new species.}

Plate 120, fig. 8; plate 123, figs. $3-4$; plate 124 , fig. 4.

Type specimen.-A right hinder cannon bone, lacking the lower split end. (Cat. No. 10166).

Type locality.-Coconino Forest plateau, Arizona.

Type formation.--Lower Pleistocene.

Diagnosis.-Animal with long and slender limbs and, as shown by a referred axis, long necked, the hinder cannon bone, on the middle third of the shaft, with rounded front and lateral faces and with a deep hinder groove (pl. 120, fig. 8.)

A smaller camel than the dromedary is indicated by an injured axis, the greater part of a hinder cannon bone, and some first phalangeals. It appears to have been a slender, long-necked, and longlegged animal. The axis (Cat. No. 10167) lacks the hinder end. In all probability this missing portion was in the deposit, but was not collected. In size the bone is intermediate between that of the llama and that of the dromedary. An estimate based on the axes of the species just mentioned indicates that the length of the centrum of

15 Leidy and Lucas, as cited, pl. 18, fig. 2. 
the fossil bone would be about $130 \mathrm{~mm}$. That part present, from the front of the odontoid process to the rear of the neural arch, is $125 \mathrm{~mm}$. long; and there is still no indication of the ridges that must have run forward from the postzygapophyses. The width of the bone, across the front end is $50 \mathrm{~mm}$. The width, $80 \mathrm{~mm}$. behind the front end, is $26 \mathrm{~mm}$; the height, $39 \mathrm{~mm}$. On the part of the bone preserved there are no, or very obscure, indications of the wing-like transverse processes that are present on the axis of the llama and that of the dromedary; nor is there any beginning of the posterior enlargement of the median ridge on the lower face; likewise none of the posterior enlargement of the crest of the neural arch.

The fragment of cannon bone (pl. 124, fig. 4) is $288 \mathrm{~mm}$. long. It is complete above, but does not quite reach the split at the lower end. The hinder face is occupied by a broad groove. At the upper articular surface the side-to-side diameter is $44 \mathrm{~mm}$; the greatest foreand-aft diameter, $40 \mathrm{~mm}$. At a point $125 \mathrm{~mm}$. below the upper articular surface the fore-and-aft diameter is $32 \mathrm{~mm}$. on the outer face; $25 \mathrm{~mm}$. in the median plane. Figure 8 of plate 120 presents a section at this point. The lateral faces are convex and nearly parallel; the front face is rounded. At the lower end the fore-andaft diameter is $22 \mathrm{~mm}$; the side-to-side diameter, $28 \mathrm{~mm}$. This bone is to be compared with the corresponding one of $P$. minimus. ${ }^{16}$ Similar parts of the two bones are preserved. The two agree in having a strong ridge running down in front of the process at the rear of the upper articular surface. In this they differ from both the dromedary and the llama. A comparison of figure 8 of plate 120 and figure 9 of plate 120 will show that the cross sections, taken 125 $\mathrm{mm}$. below the upper ends, are very different. In section the bone of $P$. major resembles that of the dromedary, while that of $P$. longurio is not greatly different from the corresponding bone of the llama. Two first phalangeals (Cat. No. 10168) are present and are taken to be the anterior. One has lost the epiphysis. The other is here illustrated (pl. 123, fig. 3).

The following comparative measurements are given:

Measurements of anterior first phalangeals.

Length of bone in its median plane.

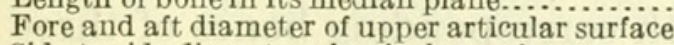

Side-to-side diameter of articular surface

Width of distal articular surface.

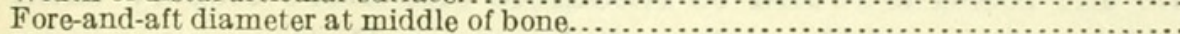

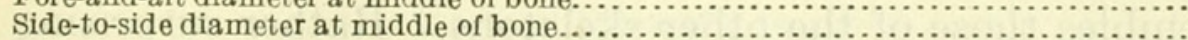
\begin{tabular}{c|c} 
Pro- & Drom- \\
camelus & Drom
\end{tabular} longurio

\begin{tabular}{c|c}
111 & 94 \\
$33 \pm$ & 34 \\
28 & 41 \\
22 & 35 \\
20 & 21 \\
16 & 21
\end{tabular}

${ }^{16}$ Leidy and Lucas, p. 60, pl. 16, fig. 1.

27177-21-Proc.N.M.vol.59 
The measurements show that the proximal phalangeals of Procamelus longurio differ much from those of the dromedary, being at once longer and much slenderer. The shaft in the dromedary is flattened from front to rear; in the fossil, from side to side. These bones resemble more those of the llama. There is present what is taken to be the distal half or more of a hinder first phalange (pl. 123, fig. 4) of the same species (Cat. No. 10169.) Its length must have been $90 \mathrm{~mm}$. or more. At what is thought to be the middle of the length the fore-and-aft diameter is $19 \mathrm{~mm}$; the side-to-side diameter, $13 \mathrm{~mm}$. The width of the lower articular surface is $20 \mathrm{~mm}$; but here, as in the hinder phalangeals, the width increases somewhat backward on the lower surface. This phalange is to be compared with the phalange, probably a hinder one, figured by Leidy and Lucas, ${ }^{17}$ and referred to $P$. minimus. The one from Arizona was evidently longer than the one from Florida, which measures $87 \mathrm{~mm}$. At the middle of its length the latter has a fore-and-aft diameter of $16 \mathrm{~mm}$; a side-to-side diameter of $14 \mathrm{~mm}$. The former is therefore a more compressed bone. Its distal articular surface is considerably wider and extends upward farther on the lower surface.

To this species are referred a number of fragmentary bones which are smaller than those of a dromedary and apparently too small to have belonged to $P$. coconinensis. An injured lumbar vertebra (Cat. No. 10170) had a length of about $60 \mathrm{~mm}$. The anterior end of the centrum is $52 \mathrm{~mm}$. wide. The excavation for the zygapophyses of the preceding vertebra is $33 \mathrm{~mm}$. wide. Somewhat less than the inner half of the distal articular surface of the right humerus has the catalogue number 10171. The front to rear diameter is $67 \mathrm{~mm}$. The distal end of a right radius (Cat. No. 10172) has the surface for the first row of carpals $50 \mathrm{~mm}$. wide. There is present a part of the upper end of an anterior right cannon bone (Cat. No. 10173). A good deal of the inner side is gone. The width of the upper articular surface must have been about $60 \mathrm{~mm}$. Two pieces of the distal end of one or two cannon bones (Cat. No. 10174) are preserved. They may belong to the same leg. One articular surface is $35 \mathrm{~mm}$. wide. A second phalange (Cat. No. 10178), belonging apparently to the hinder foot, is $50 \mathrm{~mm}$. long.

\section{Family BOVIDAE.}

\section{ANTILOCAPRA AMERICANA Ord.}

Apparently this species is represented by a single first phalange (Cat. No. 10179). On comparison with corresponding bones of three recent skeletons the fossil is found to resemble one more closely than the latter resembles those of the other skeletons. Rather surprising differences in proportions exist in these bones of the existing pronghorn.

${ }^{17}$ Work cited, pl. 18 , fig. 8 . 


\section{Family SCIURIDAE.}

MARMOTA ARIZONAE, new species.

Plate 123, figs. 6-8.

Type specimen.-The front two-thirds of a skull (Cat. No. 10181).

Type locality.-Coconino Forest region, Arizona.

Type formation.-Early Pleistocene.

Diagnosis.-Belonging near to or within the flaviventer group of the genus. Snout narrower and more rounded than in M.f. obscura. Nasal processes of premaxillae broader than in the just mentioned subspecies. Incisors obsoletely striated.

A species of marmot belonging apparently to the group of $M$. flaviventer is represented by the anterior part of the skull of one individual and two molar teeth of another. On comparison of the skull with that of a specimen of $M$. flaviventer obscura-a female from San Miguel county, New Mexico-differences appear which, on the discovery of additional materials, may prove to be of specific or of only subspecific value. At the present day no species of marmot is known to live within the territory of Arizona; and New Mexico harbors only in its northern part the subspecies named above- $M$. flaviventer obscura.

Figures 6-8 of plate 123 present views of the specimen on which the new species is based. The incisor teeth are broken off at the bone. On the right side, three molars, little worn, are present; on the left side, only one. The nasal bones and the zygomatic arches are missing. The distance from the rear of the last molar to the front of the premaxillae is $47 \mathrm{~mm}$. In the recent skull used for comparison this distance is $46 \mathrm{~mm}$. The nasal process of each premaxilla is nearly as wide as the space occupied by both of the nasals. The width of the frontals at the front of the orbits is somewhat less than in the recent skull. Examined from below, the snout is narrower in the fossil. The width at the maxillo-premaxillary suture is $19 \mathrm{~mm}$; in the recent skull, $20 \mathrm{~mm}$. The palate behind the incisors is more rounded from side to side. In the recent skull a ridge running back on each side from the incisor gives an effect of squareness to this region. The processes on the maxillae just in front of the rows of teeth appear to be unusually strongly developed in $M . f$. obscura. They are much less prominent in the fossil. No differences are observed in the rows of teeth or of the individual molariform teeth. The incisors of $M . f$. obscura are very distinctly striated; in the fossil they are nearly smooth.

\section{CITELLUS TUITUS, new species.}

Plate 120, figs. 5-6.

Type specimen.-The anterior half of a skull, with incisors and all the upper teeth except the third premolars (Cat. No. 14353 of the Amer. Mus. of Nat. History). 
Type locality.-Coconino Forest plateau, Arizona.

Type formation.-Early Pleistocene.

Diagnosis.- Size about that of Citellus franklini. Rows of upper teeth converging backward. Palate narrow.

The skull which is made the type of this species presents that part which lies in front of the brain case. This part is damaged and slightly distorted. The small foremost premolars $\left(\mathrm{pm}^{3}\right)$ are missing. The other teeth are in fine condition. A part of one nasal bone is present, but displaced. Most of the left premaxilla is missing. Much of the bone is covered with a coating of calcite.

In size this animal resembled $C$. franklini. Its conspicuous character is the convergence of the rows of upper teeth backward. The following comparative measurements are presented:

Measurements of skulls of Citellus.

\begin{tabular}{|c|c|c|}
\hline 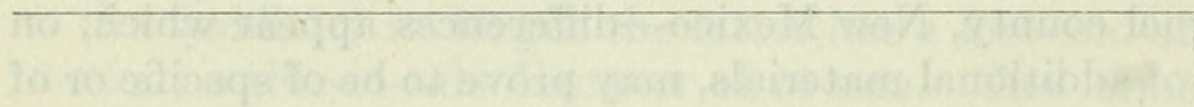 & $\begin{array}{l}\text { C. frank- } \\
\text { lini. }\end{array}$ & C.tuitus. \\
\hline 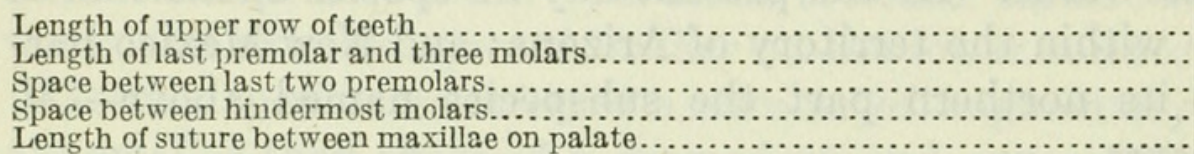 & $\begin{array}{r}10 \\
9 \\
8 \\
7 \\
13.5\end{array}$ & $\begin{array}{r}10.8 \\
9.6 \\
7 \\
5.6 \\
13.5\end{array}$ \\
\hline
\end{tabular}

It will be observed that, while the rows of teeth are slightly longer in C.tuitus than in C. franklini, the palate is narrower at each end, and that the rows approach each other more rapidly in the fossil.

While the bones and teeth are colored green by the copper, there are yet traces, on the enamel of the incisors, of the original orange color.

\section{Family CRICETIDAE.}

\section{NEOTOMA CINEREA Ord.}

In the collection made by Mr. Brown for the American Museum of Natural History, in New York, there is a right ramus which is not distinguishable from that of Neotoma cinerea. It contains all of the grinding teeth except the hindermost. The catalogue number is 14365 of the American Museum.

\section{LEPUS BENJAMINI, new species.}

Plate 121, figs. 1-5b.

Type specimens.-A part of a left ramus, containing the premolars and molars, except the hindermost (Cat. No. 10183).

Type locality.-Coconino plateau, Arizona.

Type formation.--Early Pleistocene.

Diagnosis.-Differing, so far as known, from Lepus campestris only in having the enamel of the outer infold of the lower molariform teeth distinctly crenulated behind. 
Named in honor of Dr. Marcus Benjamin, editor of the Proceedings of the the United States National Museum.

Besides the fragment of the lower jaw which is made the type of this species there is a considerable number of other parts referred to it provisionally. The principal of these are the following: A right upper incisor (Cat. No. 10184); the greater part of both maxillae (Cat. No. 10185), containing the left first true molar and the sockets of the other teeth, excepting the front premolar; an interparietal bone (Cat. No. 10186); one lumbar vertebra (Cat. No. 10187); a complete humerus (Cat. No. 10198); five fragments of innominate bones (Cat. Nos. 10189, 10190); three complete femora (Cat Nos. 10191, 10192); the upper half of a right tibia (Cat. No. 10193); a tibia lacking the upper epiphysis and a part of the distal end (Cat. No. 10194); and a distal end of another tibia (Cat. No. 10195). These bones are described below:

The type ramus is figured (pl. 121, fig. 1) as seen from the inner side. The height at the first molar is $16 \mathrm{~mm}$. The anterior premolar is only slightly larger than the other teeth. In it, as in the other teeth, the enamel is thin and delicate, thickest where it forms the front wall of the main outer valley. In the anterior tooth this front wall is angulated and slightly wavy in its course. The rear part of the loop is very thin and distinctly crenulated. In the front border of this tooth there is a narrow but pretty deep inflection of the enamel. In the outer face of the front half of the tooth there is a wider inflection of the enamel, and this also is crenulated. In the other teeth the anterior part of the loop of enamel is thickened and forms a ridge across the grinding surface. The hinder part of the loop is crenulated. The writer was on the point of referring the fossil to Lepus campestris, but an examination of many specimens of its various subspecies resulted in finding that in none of them did the hinder element of the loop show more than feeble traces of crenulations. Other species, as L. alleni and L. gaillardi,. present these constantly. These species, however, differ in other ways from the fossil species.

Figure 2 of plate 121 presents a view of two maxillae of one individual which is believed to belong to the species described. The right first molar is present. The parts resemble the corresponding ones of L. campestris. A complete upper right incisor appears not to differ from that of the species just named. The groove is nearer the inner border of the tooth, and it retains its cement. L. californicus rarely has cement in the grooves of the incisors.

The lumbar vertebra present resembles more that of a species of Sylvilagus than of Lepus. Perhaps it does not belong to the species being described. The humerus (pl. 121, fig. $5 a$ ) is $91 \mathrm{~mm}$. long. It is somewhat more compressed than one $95 \mathrm{~mm}$. long and supposed to 
belong to Lepus callotis. At the middle of the length the fore-and-aft diameter is $6.6 \mathrm{~mm}$; the side-to-side diameter, $4.1 \mathrm{~mm}$. In the recent humerus mentioned the diameters are $6.1 \mathrm{~mm}$. and $5 \mathrm{~mm}$., respectively.

The parts of the innominate bones present (pl. 121, fig. $5 b$ ) resemble those of the supposed L. callotis, but are slightly smaller.

The largest femur present is $115 \mathrm{~mm}$. long, quite exactly the length of that of L. "callotis." It is broader across the inner and outer processes at the upper end than in L. "callotis," and narrower across the condyles. The femur figured (pl. 121, fig. 3) is $100 \mathrm{~mm}$. long. The imperfect tibiae present are somewhat slenderer than those of the recent skeleton used for comparison. One is figured (pl. 121, fig. 4.)

\section{Genus BRACHYLAGUS Miller.}

Numerous bones of many parts of the skeleton of a species of Brachylagus are present. Usually they are more or less injured, but taken together they furnish the characters of a species apparently new. The remains appear to require some modification of the characters that have been imputed to the genus. None of the specimens retain the first upper premolar. According to Lyon ${ }^{18}$ in the next four upper molariform teeth the infolding of the enamel extends about halfway from the inner to the outer face of the tooth, and this enamel is not crenulated. However, it is seen to be occasionally slightly crenulated. In the fossil species at hand the enamel is very distinctly crenulated, and the infold appears to extend outward slightly farther than it does in $B$. idahoensis. The first lower premolar conforms to the description of that of the type species of the genus. The hinder portions of the other lower molariform teeth are smaller than the anterior portion; that is, the teeth differ from those of B.idahoensis principally in the crenulated character of the infolded enamel of the upper teeth.

BRACHYLAGUS BROWNI, new species.

Plate 121, figs. 6-18.

Type specimen.-A palate containing three grinding teeth on the right side and four on the left (Cat. No. 10196 U. S. N. M.).

Type locality.-Coconino plateau, Arizona.

Type formation.-Early Pleistocene.

Diagnosis. - Size larger than that of $B$. idahoensis. Upper molariform teeth with the enamel of the inner reentrant fold distinctly crenulated.

This species, as represented by the skull, was larger than $B$. idahoensis, but the rest of the skeleton indicates an animal of nearly the same size. Perhaps the skull was that of an unusually large

18 Smiths. Misc. Coll., Quart. Issue, vol. 50, p. 412. 
individual. The front half (Cat. No. 10197) is here figured (pl. 121, figs. 7-9). It has been impracticable to remove all of the calcite and sand, but the form of the skull is shown. From the rear of the hinder tooth to the front of the snout is $28 \mathrm{~mm}$; in a specimen of the living species from Nevada this distance is only $23 \mathrm{~mm}$. The nasal bones, the incisors, and some of the other teeth are missing from the specimen figured. Figure 10 of plate 121 presents a view of a palate and maxillae (Cat. No. 10198) from which the teeth have fallen. The first premolar, to judge from the size of the socket, was larger than the corresponding tooth of $B$. idahoensis. Figure 6 of the same plate presents a view of the type - a palate (Cat. No. 10196) in which many of the teeth are retained. Another figure (pl. 121, fig. 12) gives a view of the left zygomatic arch and palate, as seen from below (Cat. No. 10199.). Some matrix yet clings to the bone. There are present several rami of lower jaws. Figure 13 of plate 121 represents one of these (Cat. No. 10200) lacking the angular process. From the rear of the condyle to the front of the jaw is $44 \mathrm{~mm}$; in a specimen of $B$. idahoensis this distance is $39 \mathrm{~mm}$. Another right ramus (Cat. No. 10201) (pl. 121, fig. 11) presents a view of the incisor and of all the other teeth except the hindermost molar. Figure 14 of plate 121 is that of a right humerus (Cat. No. 10202) $45 \mathrm{~mm}$. long; but the animal had perhaps not reached its full size. The bone is slightly shorter than the humerus of $B$. idahoensis from Nevada. One-half of a right innominate bone (Cat. No. 10203) is shown as seen from below in figure 15 of plate 121 . The total length is $49 \mathrm{~mm}$; that of the specimen of $B$. idahoensis is $46 \mathrm{~mm}$. Figure 16 of plate 121 presents a front view of a right femur (Cat. No. 10204); figures 17 and 18 of the same plate show parts of two tibiae, one (Cat. No. 10206) lacking the epiphysis; the other (Cat. No. 10207) the distal half of the bone.

TAXIDEA ROBUSTA, new species.

Plate 119, figs. 3-5.

Type specimen.-A left ulna.

Type locality.-Coconino Forest region.

Type formation.-Early Pleistocene.

Diagnosis.-Ulna stouter than in T. taxus. Inner face with a ridge from coronoid process to distal end. Pubic bone at rear of obturator foramen thicker and wider than in T. taxus.

In the collection there is a single ulna (Cat. No. 10208), that of the left side, which appears to have belonged to a species of Taxidea distinct from $T$. taxus. This bone has lost all that part above the middle of the greater sigmoid cavity, and also the head and styloid process.

When compared with the corresponding bone of T. taxus (pl. 119, figs. 1,2$)$ the fossil is seen to be stouter. When measured halfway 
between the articular surface for the head of the radius and that for its distal end the diameters are found to be $8.5 \mathrm{~mm}$. and $6.2 \mathrm{~mm}$. In a humerus of $T$. taxus at hand, slightly shorter, the diameters are $8 \mathrm{~mm}$. and $5.2 \mathrm{~mm}$. The height through the coronoid process is $15.5 \mathrm{~mm}$; in $T$. taxus, $13.6 \mathrm{~mm}$. In the fossil there is a deep groove in the outer face which starts beneath the greater sigmoid cavity and runs down the bone. Beyond the middle of the length of the ulna this groove becomes shallow. In T. taxus it continues on distinctly to near the lower articular surface for the radius. On the inner face of the fossil bone a ridge starts at the coronoid process and continues to near the lower end of the ulna. At the middle of the length of the bone it approaches the hinder border; then retires from it, and ends below in a sharp crest. In T. taxus the ridge is practically missing in the middle third of the length.

Besides the ulna there is a part of the right innominate bone (Cat. No. 10209.). This (pl. 119, fig. 5) consists of the pubic bar which bounds the obturator foramen below and the part of the schium that bounds it behind. When this is compared with the corresponding parts of Taxidea taxus berlandieri, from Matamoras, Mexico (No. 1389 U.S.N.M.), they are found to be very different. The fossil bone is narrower, but much thicker. The pubic bar where narrowest is $5.4 \mathrm{~mm}$. wide and $2.8 \mathrm{~mm}$. thick; in T. taxus, $6 \mathrm{~mm}$. wide and $2.2 \mathrm{~mm}$. thick. The pubic symphysis is of about the same length in the two species, $10 \mathrm{~mm}$.; in the fossil it is $7 \mathrm{~mm}$. thick; in T. taxus, $3.3 \mathrm{~mm}$. The bar bounding the obturator foramen behind makes a greater angle with the pubic bar than it does in T. taxus. At the rear end of the obturator foramen the bone is $7 \mathrm{~mm}$. wide and $5 \mathrm{~mm}$. thick; in T. taxus, $5.5 \mathrm{~mm}$. wide and $3 \mathrm{~mm}$. thick.

\section{CANIS NUBILUS?}

Three left rami of lower jaws (Cat. No. 10210); the lower half of a right humerus (Cat. No. 10211); the lower fourth of a smaller one (Cat. No. 10212); a complete right radius (Cat. No. 10211); the distal half of another of the left side (Cat. No. 10213); an axis (Cat. No. 10214); the distal ends of two right tibiae and apparently the corresponding astragali (Cat. Nos. 10218, 10219) are referred with doubt to Canis nubilus. The humerus and the radii evidently belonged to one individual, and it seems probable that the best of the three jaws was a part of the same skeleton. The animal belonged evidently to a large and apparently slender-limbed form. The radius is longer by as much as an inch than in some gray wolves. At the same time the bones are slenderer than in those specimens. One wolf (No. 1308 of the United States National Museum), collected in 1853, at Fort Kearney, Nebraska, regarded as $C$. nubilus, has, however, a radius only slightly longer. 
Measurements of radii of wolves.

\begin{tabular}{|c|c|c|}
\hline 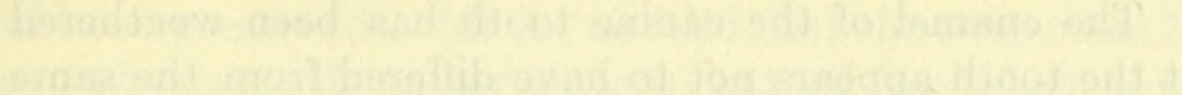 & $\begin{array}{c}C . \\
\text { nubilus? }\end{array}$ & $\underset{\text { nubilus. }}{C .}$ \\
\hline 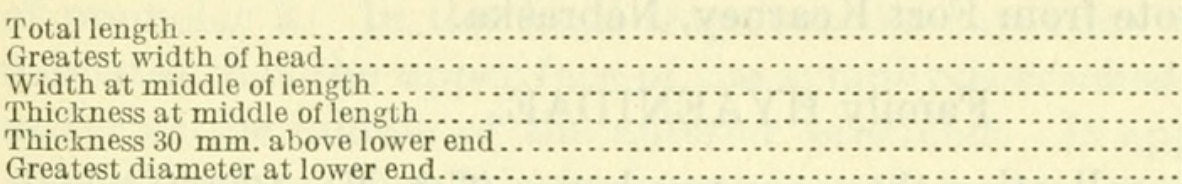 & $\begin{array}{l}202 \\
21 \\
15.5 \\
10 \\
10.5 \\
28.6\end{array}$ & $\begin{array}{c}204 \\
23 \\
16 \\
11.6 \\
13.5 \\
30.6\end{array}$ \\
\hline
\end{tabular}

The thickening of the bone in the distal half is especially noticeable. The humerus of the wolf No. 1308 is $205 \mathrm{~mm}$. long. The length of the fossil can not be determined. It is assumed to have been closely the same.

Measurements of humeri of wolves.

Total length.

Fore-and-aft diameter $102 \mathrm{~mm}$. above lower end

Side-to-side diameter $102 \mathrm{~mm}$. above lower end.

Width of lower articular surface.

Width across condyles at lower end...

The best preserved ramus of the lower jaw, in comparison with that of $C$. nubitus, is lower and thinner. The teeth differ apparently only in being thinner. The canine, as shown by a part of the socket present, was slender.

Another fragment of a left ramus is similarly low, but is thicker. The fourth premolar is as thick as in $C$. nubilus. A third left ramus had early lost the carnassial tooth by disease. The socket is filled with bone and the jaw is swollen in that region. The fourth molar is longer and thicker than in C. nubilus. A complete axis is of a size corresponding to the other bones. It appears probable that all of these parts belong to $C$. nubitus or to a species very close to it.

In the American Museum of Natural History there is a fragment of a left ramus of a lower jaw (Cat. No. 14360) which contains the last two molars. It probably belongs to the same species as the others. An atlas in the same collection is to be similarly referred.

In addition to these bones there are some of a smaller individual, a cervical vertebra, apparently the seventh, and a dorsal vertebra, about the fifth (Cat. No. 10220); the distal ends of two tibiae and the corresponding astragali (Cat. Nos. 10218, 10219).

CANIS LATRANS Say.

Canis latrans, or a species close to it, is represented by a part of a right tibia (Cat. No. 10221) and an upper left canine (Cat. No. 10222). The fragment of tibia is $113 \mathrm{~mm}$. long, and lacks a little of the upper 
end and several millimeters of the lower. On comparison with the same part of a specimen of $C$. latrans from Nebraska no differences are observed. The enamel of the canine tooth has been weathered somewhat, but the tooth appears not to have differed from the same tooth of a coyote from Fort Kearney, Nebraska.

\section{Family HYAENIDAE.}

In the Anita collection there are two bones (Cat. No. 10223) which the writer regards as having belonged to one specimen of some carnivorous animal; these are parts of the left ramus of one or two lower jaws. The principal fragment is that which bore the last premolar and the first molar, together with the lower border of the jaw, extending back to the condyle and the angle (pl. 124, figs. 5, 6). This was at first regarded with some doubt as having belonged to a large species of Felis. Unfortunately the crowns of the teeth are gone, but the roots remain; also a slight part of the grinding surface of the rear of the fourth premolar. In front of the fourth premolar there is preserved a small patch of the hinder wall of the socket for the hinder root of the third premolar. This root seems to have been about as large as the anterior root of the fourth premolar.

The other fragment mentioned belonged to a left ramus, and presents the hinder wall of the socket for the canine, and for three roots of premolars (pl. 124, figs. 5, 6, upper end). As to these premolars, it was at first a question whether the second root belonged to the first premolar present or to the second. An examination of the wall of bone between two premolars of a dog or large felid shows that both of its faces are quite uniformly concave. On the other hand, the wall that separates two roots of a premolar has its two faces nearly flat; while in the middle of each face there is a more or less distinct ridge. Each ridge fits into a slight groove on the corresponding face of the root. Now in the fragment under consideration the bone which separates the two roots present indicates distinctly that they belong to one tooth; while the bony septum next behind shows as conclusively that it separated two different teeth. We find, therefore, that the premolar succeeding the canine had two roots. We must now determine whether either or both of the fragments belonged probably to a felid or to some other group. The anterior fragment will be first considered.

(a) The diastema between the canine and the first premolar present measures only $10 \mathrm{~mm}$. In a lion jaw at hand this measures $31 \mathrm{~mm}$.; in a tiger, $26 \mathrm{~mm}$. However, in a few cats, as the puma, this is short; in the puma, only about $10 \mathrm{~mm}$. (b) In the cats there are usually two or more mental foramina; one, large or small, beneath the anterior premolar (pm. 3), the others in front of it. (c) In the fossil bone there is a large foramen below the hinder root of the anterior pre- 
molar, but no traces of others or of their backwardly directed canals. It is possible, however, that these were lower down than in the part of bone preserved. (d) In no felid that the writer has found does the symphysis on its upper surface, extend backward beyond the front of premolar 3. In the fossil fragment the curvature of the surface indicates that the upper face of the symphysis reached back at least as far as the middle of the anterior premolar. It appears improbable, therefore, that this fragment was that of a jaw of any of the Felidae.

Now as to the larger fragment of the jaw: (a) In the cats the lower border of the ramus is nearly straight from the symphysis to the angle, so that, when placed on a level surface, the angle touches the surface or nearly so. The upper and inner border of the jaw along the tooth row then slopes slightly downward. When the fossil ramus is placed on a level surface the inner upper border of the bone slopes slightly upward in front. Unless the jaw below the anterior teeth maintained the great depth which it has behind, $51 \mathrm{~mm}$., the angle of the jaw must have been raised above the supposed level surface. (b) In the cats the surface for the insertion of the masseter muscle is nearly always deeply excavated, and the bone at the lower edge of this surface stands out as a sort of shelf. In the fossil the masseter surface is less deeply excavated. (c) In the cats, so far as observed, the depth of the jaw at the middle of the molar is considerably less than the length of the sockets of the last premolar and the molar taken together. In the fossil the two dimensions are equal. The characters just discussed, it seems to the writer, make it very improbable that the jaw belongs to Felis or any closely related genus.

The general appearance of the fragments, the similar fossilization, the filling of sediment in the canals and other openings, the size of the small fragment relative to the larger one, and the improbability that either of them belonged to a felid, make it probable that they were parts of the same jaw.

If this is the case, it appears that the jaw must be referred to the Hyaenidae, for there are three premolars, all two-rooted, the hindermost large, and a large molar, doubtless a shearing tooth. The diastema is short, as in the hyaenas. In Crocuta the symphysis comes back even with the middle of premolar 2, as it does in the fossil. There is a large single mental foramen in the position of that of the fossil. The lower border of the ramus rises from beneath the molar to the angle; and this was probably the case with the fossil jaw. The masseter excavation is comparatively shallow, as it is in the fossil. On the outer face of the jaw, beneath the molar and the last premolar, the surface is somewhat concave in the hyaenas; in the cats it is convex; in the fossil it is concave. The inferior dental foramina and canal in the cats are large; in the hyaenas they are much smaller. 
Those of the fossil jaw appear to have been about as large as in the hyaenas.

There are some features in the jaw which are different from those of both the felids and the existing hyaenas. The jaw is deeper still than in the hyaenas and it is considerably thickened along that part of the lower border preserved. The angular process is strongly developed, round, rather thin, and without the concavity seen on the inner face of the angle of the hyaenas. While it seems that the animal must be referred to the Hyaenidae, it seems quite as necessary to put it in a new genus. The name of this makes allusion to the Grand Canyon, whose beginning this animal may have witnessed.

CHASMAPORTHETES, new genus.

Type species.-Chasmaporthetes ossifragus, new species.

Diagnosis.-Differs from the existing genera in having apparently thinner premolars and molars, a deeper and thicker lower jaw, with a broad and rounded angle.

CHASMAPORTHETES OSSIFRAGUS, new species.

Plate 124, figs. 5,6 .

Type specimen.-The rear of the left ramus of a lower jaw, with roots of teeth, but with the crowns shattered. (Cat. No. 10223.)

Type locality.-Coconino Forest region, Arizona.

Type formation.- Early Pleistocene.

Diagnosis.-Fourth premolar and first molar of nearly the same length; the molar apparently thicker. Jaw deeper and thicker than in existing species. Referred second molar two-rooted and its socket nearly two-thirds as long as that of the molar. Symphysis extending back to at least the middle of the second premolar.

The following measurements in millimeters are added to the description:

\section{Measurements of jaws and teeth of hyaenas.}

\begin{tabular}{|c|c|c|}
\hline 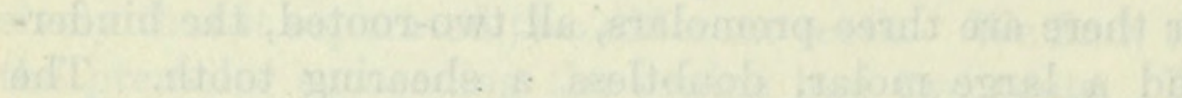 & $\begin{array}{l}\text { Chasma- } \\
\text { porthetes. }\end{array}$ & Hyaena. \\
\hline 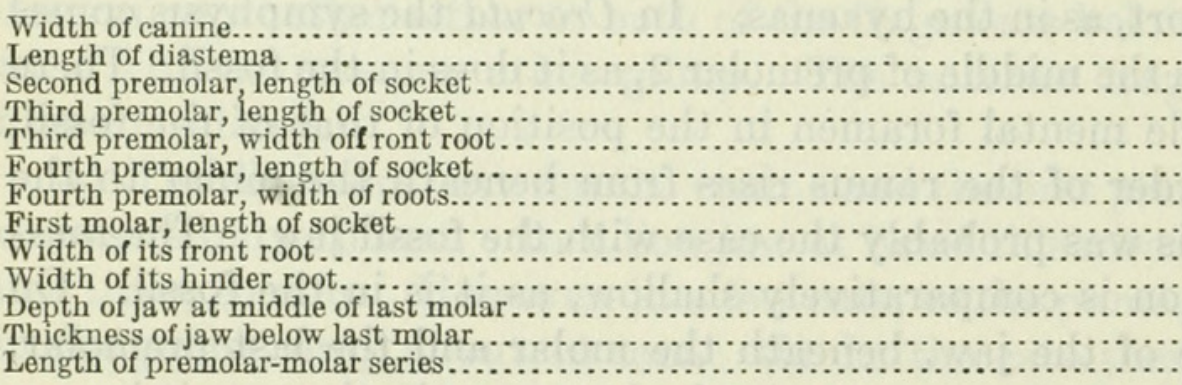 & $\begin{array}{l}11 \pm \\
10 \\
18 \\
19 \\
7 \\
25 \\
8 \\
27 \\
8 \\
6 \\
49 \\
17 \\
90 \pm\end{array}$ & $\begin{array}{r}10.5 \\
10.2 \\
13.5 \\
17.2 \\
9 \\
17.5 \\
9 \\
17 \\
8 \\
6 \\
37 \\
11 \\
70\end{array}$ \\
\hline
\end{tabular}


It will be seen that the fossil animal was apparently a somewhat larger one than that with which it is here compared. If this is taken into account, some differences are not so great as they appear to be. The second premolar of the fossil would be relatively of about the same length as that of the living species; the fourth premolar somewhat longer, the first molar considerably longer. On the other hand, the roots of the teeth, probably the crowns also, would be relatively thinner.

In size of jaw and length of teeth the fossil species resembles more Crocuta crocuta. The crowns of the teeth appear to have been thinner than in either of the living species. Although the teeth of Crocuta are larger than those of Hyaena the jaw is but little longer.

Besides the parts described above, there is a root of a large canine which resembles closely the root of an upper canine of a hyaena, also a left mandibular condyle which differs little from that of Hyaena hyaena. It is possible that it belongs to the mandible forming the type of the species here described, but contact between the two fragments can not be established.

Having described the species found at Anita it appears proper to consider what may be learned from that assemblage. By far the larger number of the species are such as are generally recognized as belonging to the Pleistocene. While horses and true dogs (Canis) may yet be found to occur in Pliocene deposits, it is not yet proved that they do so occur. The preservation of the bones and teeth in a limestone cave itself indicates that they belong to the Pleistocene; yet among these Pleistocene animals are found remains of two camels which it seems necessary to refer to the genus Procamelus. Members of this genus have not usually been recognized as having existed at a later time than the early Pliocene. In $1916^{19}$ Dr. E. H. Sellards referred to the apparent admixture of Pliocene and Pleistocene species that had been observed in the Dunnellon (Alachua) formation in Florida. Among the fossils were three species of Procamelus - P. major, P. minor, and $P$. minimus. The two species of the same genus found at Anita are so closely related to two of those from Florida, $P$. major and $P$. minimus, that it was at first thought that they were the same. The writer has briefly discussed this Florida case ${ }^{20}$ also the finding of similar mixtures of Tertiary and Pleistocene fossils in Idaho and in Oregon. In these western localities, as well as in Florida, there have occurred, it has been supposed, either in the deposits or in the collections, accidental minglings of fossils of two distinct formations. At Anita, however, there can have happened nothing of the sort,

19 Eighth Ann. Rep. Fla. Geol. Surv., p. 94.

${ }^{20}$ Amer. Journ. Sci., Ser. 4, vol. 47, p. 373. 
and it appears therefore that Procamelus is definitely brought up into the Pleistocene. It is too early to say that the same thing will happen for the rhinoceroses, but it may be expected. The explanation given by the author in the article cited above is that the mentioned deposits in Florida, Idaho, and Oregon belong to the time of the first glacial, or Nebraskan, stage of the Pleistocene. The collection made at Anita, Arizona, appears to give testimony for this view.

\section{ON SOME ADDITIONAL FOOT BONES OF THINOBADISTES SEGNIS FROM FLORIDA.}

Plate 119, figs. 6-11.

In $1919,{ }^{21}$ the writer described a new genus and species of ground sloth (Thinobadistes segnis). This species was based on a left astragalus which had been found in "Mixon's bone bed," near Williston, Levy County, Florida, in 1887. Since that description was written, seven other foot bones which had been found at the same time and place, have come to light in the United States National Museum. In all probability these belonged to the same individual as the astragalus.

The rediscovered bones are the navicular, the third, the fourth, and the fifth metatarsals of the right hinder foot, the second phalange of the right hinder foot, the proximal end of the ungual phalange of the same digit, and the right second metacarpal.

The right second metacarpal (Cat. No. 2509a; pl. 119, p. 6) has about the size of that of Mylodon robustus. ${ }^{22}$ The total length of the bone is $78 \mathrm{~mm}$.; the height at the distal trochlear ridge, $46 \mathrm{~mm}$. Owen's description of this bone in Mylodon ${ }^{23}$ applies well to the one in hand. The navicular (Cat. No. 2509b; pl. 119, fig. 7) conforms to the description given in Owen's article cited. Its side-to-side dimension is 68 $\mathrm{mm}$.; its width, somewhat more than $41 \mathrm{~mm}$., being thus somewhat smaller than that of Mylodon robustus. ${ }^{24}$ Compared with the same bone of Mylodon sodalis, it is considerably smaller, thinner, narrower, and has the surface for articulation with the cuboid at right angles with the surface for the astragalus, while in $M$. sodalis it is oblique to that surface. The third metatarsal (Cat. No. 2509c; pl. 119, fig. 8) is much like that of Mylodon robustus, but it appears to be somewhat larger. Its greatest axial length is $70 \mathrm{~mm}$. It differs from the corresponding bone of Mylodon robustus in having a facet on the inner side of the proximal end for the second metatarsal. It is near the lower border of the bone and looks downward. This facet is about $18 \mathrm{~mm}$. long and $11 \mathrm{~mm}$. wide. Below it the surface of the bone is rough, as though the base of the second metatarsal had been closely bound to the third.

${ }_{21}$ Proc. U. S. Nat. Mus., vol. 56, p. 104, pl. 27.

22 Owen, Monogr. Mylodon, pls. 15, 16.
23 Idem, p. 91.

24 Idem, p. 175. 
In general terms the description of the fourth metatarsal of Mylodon robustus applies to the corresponding one of Thinobadistes (Cat. No. $2509 d$, pl. 119, fig. 9). However, the latter is narrower at its distal end and gradually widens upward. It has a total length of $102 \mathrm{~mm}$.; the height of the distal end is $46 \mathrm{~mm}$. The fifth metatarsal (Cat. No. 2509e; pl. 119, fig. 9) has a length of $127 \mathrm{~mm}$., very close to that of Mylodon robustus. The greatest width of the proximal end is $56 \mathrm{~mm}$. A comparison with Owen's figure will show that the distal half of this bone is differently shaped in the two animals. In $M$. robustus the outer border is nearly straight; in the Florida animal the border is sigmoid. The distal end of the fifth metatarsal reaches nearly to the distal end of the fourth; in $M$. robustus it falls considerably short of reaching that point. The proximal end of the outer border of this metatarsal is thick, and rounded; and it forms part of a smooth surface which continues around to the underside of the bone. This surface was probably covered by a pad of thickened skin and bore much of the weight of the animal.

The second phalanx in the collection appears to belong to the median digit of the right hind foot (pl. 119, fig. 10). The total length is $50 \mathrm{~mm}$; that taken along the axis of the bone $38 \mathrm{~mm}$. The height of the hinder end, taken in the median plane, is $33 \mathrm{~mm}$.; the width of this end, $35 \mathrm{~mm}$. ; the width of the distal articulation, about $25 \mathrm{~mm}$. The base of an ungual phalanx (pl.119, fig. 11) is taken to be that of the hinder third digit, and it fits closely to the end of the second phalanx just described. The height of the hinder end of the bone is $45 \mathrm{~mm}$; the width, $38.5 \mathrm{~mm}$. On the sides of the base of the phalanx are indications of the presence of the sheath for the horny claw; but, as represented in Owen's figure of the hinder median claw, this sheath was deficient on the middle of the upper surface.

It will be a matter of great interest to discover additional remains of this animal, especially remains of the skull and teeth. In the hinder foot the digits resemble much those of Mylodon; but the astragalus, especially on the underside, is much like that of Megatherium. The size of the animal was about that of Mylodon robustus, but considerably smaller than Mylodon sodalis from Christmas Lake.

\section{EXPLANATION OF PLATES.}

\section{Plate 116.}

Figs. 1-7. Camelops huerfanensis. Upper teeth. $\times .7 \pm$ :

1. Right fourth premolar, grinding surface.

2. Right first molar, outer face.

3 . Same tooth, grinding surface.

4. Right second molar, outer face.

5. Same tooth, grinding surface.

6. Right third molar, outer face.

7. Lower left hindermost molar. 
Figs. 8-9. Camelops, species indeterminable. Lower left third molar. $\times .66$ :

8. View of inner face.

9. View of grinding surface.

Plate 117.

All the figures are of approximately the natural size.

Fig. 1. Odocoileus, species indeterminable. Distal end of cannon bone and first phalange.

2. Marmota monax. Left side of lower jaw.

Figs. 3-5. Marmota arrodens. $\times 1$ :

3. Right side of mandible, with incisor. Type.

4. Left ramus, with incisor.

5. Right humerus, front view.

Fig. 6. Marmota monax. Right humerus, front view.

7. Marmota arrodens. Right ulna.

8. Marmota monax. Right ulna.

9. Marmota arrodens. Right radius.

10. Marmota monax. Right radius.

Plate 118.

All the figures are of approximately the natural size.

Fig. 1. Marmota arrodens. Upper end of left femur, rear view.

2. Marmota monax. Upper end of femur, rear view.

Figs. 3, 4. Marmota arrodens. Tibiae:

3. Left tibia.

4. Right tibia.

Fig. 5. Marmota monax. Right tibia.

Figs. 6-8. Marmota flaviventer. Skull:

6. Skull seen from above.

7. Same skull seen from below.

8. Frontal bone of another skull.

Figs. 9, 10. Thomomys fuscus. Front of skull.

9. Seen from below.

10. Seen from right side.

FIG. 11. Equus occidentalis? Upper right second premolar.

12. Equus giganteus? Part of an anterior fossette of upper left tooth.

Plate 119.

Figs. 1-2. Taxidea taxus. Left ulna. $\times 1$.

1. Inner face.

2. Outer face.

Figs. 3-5. Taxidea robusta.

3. Inner face of left ulna. $\times 1$.

4. Outer face of left ulna. $\times 1$.

5. Part of right ischium and pubis, showing upper face. $\times .5$.

Figs. 6-11. Thinobadistes segnis. Foot bones. $\times .5$ :

6. Right second metacarpal, seen from below.

7. Right navicular, seen from behind.

8. Right third metatarsal bone, seen from left side.

9. Right fourth and fifth metatarsal bones, seen from below.

10. Second phalange of right hinder median digit, from above.

11. Base of ungual phalange of hinder third digit, from behind.

Fig. 12. Camelus arctoamericanus. Anterior first phalanx, seen from rear. $\times .7$. 


\section{Plate 120.}

Figs. 1-4. Thomomys scudderi. Skull. Type:

1. Skull seen from left side. $\times 1$.

2. Right ramus of lower jaw seen from right side. $\times 1$.

3. Skull showing palate. $\times 2$.

4. Lower jaw seen from above. $\times 2$.

Figs. 5-6. Citellus tuitus. Skull. Type. $\times 2$ :

5. Palate, showing teeth.

6. Left side of skull.

Fig. 7. Citellus taylori. Type. $\times 1$. Left ramus of lower jaw seen from left side.

Fig. 8. Procamelus longurio. Type. $\times 1$. Section of the right hinder cannon bone.

Fig. 9. Procamelus major Leidy. Section of the right hinder cannon bone.

Plate 121.

All the figures are of approximately the natural size.

Figs. 1-5. Lepus benjamini:

1. Lower jaw. Type. Inner face of left ramus

2. Referred maxilla.

3. Right femur, front view.

4. Right tibia, front view.

$5 a$. Left humerus, front view.

$5 b$. Right innominate bone.

Figs. 6-18. Brachylagus browni:

6. Palate, with teeth. Type.

7. Referred skull, showing right side. The bone encrusted with calcite.

8. Same skull, seen from above.

9. Same skull, seen from below.

10. Palate of another skull, showing tooth sockets.

11. A right mandible with most of the teeth.

12. A left maxilla showing zygomatic arch.

13. A right ramus of the lower jaw.

14. A right humerus seen from radial side.

15. Right innominate bone.

16. Right femur seen from in front.

17. Right tibia, lacking the epiphyses.

18. Upper half of left tibia.

\section{Plate 122.}

Figs. 1-3. Camelops huerfanensis? A cervical vertebrae. $\times . \quad .5 \pm$ :

1. Seen from below.

2. Seen from the right side.

3 . Seen from in front-

(aa) Span of the front and lower parts of the transverse processes.

(bb) Span of the lower plate of the transverse processes.

Figs. 4-6. Procamelus coconinensis. Tooth and first phalange:

4. An upper left second(?) molar. Type. $\times 1$.

5. Same tooth, presenting outer face. $\times 1$.

6. Anterior first phalange. $\times .7$.

Fig. 7. Cynomys niobrarius. Palate presenting the teeth. Type. $\times 1$. 27177-21-Proc.N.M.vol.59- 41 


\section{Plate 123.}

Fig. 1. Camelus maximus. An anterior first phalange. Type. $\times .72$.

Fig. 2. Procamelus huerfanensis. Front first phalange. $\times .75$.

Figs. 3-4. Procamelus longurio. First phalangeals. $\times .73$.

3. Anterior first phalange, seen from front.

4. Hinder first phalange, seen from front.

Fig. 5. Procamelus coconinensis. Hinder first phalange. $\times .73$.

Figs. 6-8. Marmota arizonae. Skull. Type. $\times 1$ :

6. Skull seen from below.

7. Same skull seen from above.

8. Same skull seen from the right side.

Plate 124.

Fig. 1. Equus occidentalis? Right hindermost molar. Polished section. $\times 1$. Figs. 2-3. Equus giganteus? $\times 1$.

2. Right hindermost molar. Grinding face.

3. Part of a right upper molar. $\times 1$.

Fig. 4. Procamelus longurio. Right hinder cannon bone. Type. $\times .5$.

Figs. 5-6. Chasmaporthetes ossifragus. Parts of left ramus of lower jaw. Type. $\times 1$.

5. Seen from outside.

6. Seen from above-

(a) Rear of socket for canine.

(b) Front root of second premolar.

(c) Hinder root of second premolar.

(d) Socket for front root of third premolar.

(e) Part of socket for hinder root third premolar.

(f) Front root of fourth premolar.

$(g)$ Hinder root of fourth premolar.

(h) Front root of first molar.

(i) Rear root of first molar. 


\section{$2 \mathrm{BHL}$ Biodiversity Heritage Library}

Hay, Oliver Perry. 1921. "Descriptions of species of Pleistocene Vertebrata, types or specimens of most of which are preserved in the United States National Musum." Proceedings of the United States National Museum 59(2391), 599-642. https://doi.org/10.5479/si.00963801.59-2391.599.

View This Item Online: https://www.biodiversitylibrary.org/item/32485

DOI: https://doi.org/10.5479/si.00963801.59-2391.599

Permalink: https://www.biodiversitylibrary.org/partpdf/18499

\section{Holding Institution}

Smithsonian Libraries

\section{Sponsored by}

Smithsonian

\section{Copyright \& Reuse}

Copyright Status: NOT_IN_COPYRIGHT

This document was created from content at the Biodiversity Heritage Library, the world's largest open access digital library for biodiversity literature and archives. Visit BHL at https://www.biodiversitylibrary.org. 